\section{MÁS ALLÁ DE LA CINEFILIA Y LA MITOMANÍA. LAS ESCRITORAS ESPAÑOLAS ANTE EL CINE}

\author{
Carmen Peña Ardid \\ Universidad de Zaragoza \\ C/ Pedro Cerbuna, 12 \\ 50005-ZARAGOZA \\ cpardid@unizar.es
}

\section{BEYOND CINEFILIA AND MITONAMÍA. THE SPANISH WRITERS BEFORE THE CINEMA}

\begin{abstract}
This article studies the presence of cinema in the oeuvre of several twentieth-century Spanish female writers, focusing not only on its aesthetic impact on literary forms - most clearly manifested in the film-inspired themes and resources -, but also on the way those female writers convey their varied and complex experiences as film spectators in their works, leaving critical evidence of their often ambivalent attitude towards mainstream cinematic representation, narrative patterns and cultural configurations.
\end{abstract}

KEY WORDS: Literature and Cinema; twentieth-century spanish women writers; spanish cinema.

\begin{abstract}
RESUMEN: Este artículo estudia la presencia del cine en la obra de varias escritoras españolas del siglo $X X$, atendiendo no sólo a las formas que ha adoptado su impacto estético - manifiesto en temas $y$ recursos de inspiración fílmica-, sino al modo en que dichas escritoras, en tanto espectadoras "femeninas" con identidades complejas y muy diferenciadas, se sirven de los espacios de la literatura para dejar constancia crítica de su posición ambivalente hacia la representación cinematográfica y la influencia de sus configuraciones culturales.
\end{abstract}

PALABRAS CLAVE: Literatura y Cine; escritoras españolas del siglo XX; cine español.

- iVenid al cine! -todas las manos que, juntas en manojo son de bulto como mi corazón, se me han ofrecido.

-iYo, yo, yo!

Cuesta adelante, en el gris verdoso de la tarde, yo subo con mis alegres compañeras; son niñas muy pobres, hijas de pescadores, que van descalzas, pero que sonríen.

Un aletazo del viento rompe la fila de delantales remendados.

-No tengáis miedo. Estoy yo aquí.

Y me incorporo sobre el temblor del aire, fuerte como un árbol, llena de hojas diminutas que anhelan la felicidad de las imágenes doradas que yo les he brindado.

(Carmen Conde, "El cine en la playa", 1934)

Que me caso vestida de blanco y que hago recados y visitas y comidas y maletas y que voy al cine siempre con el mismo señor, con eso nunca sueño...

(Carmen Martín Gaite, Nubosidad variable, 1992)

Mayor sensación de basura proporciona la víctima siguiente.

La descubrimos de un modo sinuoso e indirecto, a través de un movimiento de la cámara encuadrando un bidón de plástico blanco que baja por un curso de agua hasta que aparece en campo una prenda

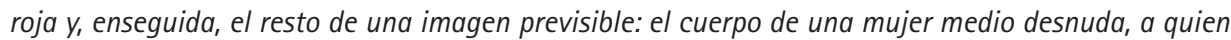
la compañía del bidón convierte en el emblema más patético del desecho.

(Pilar Pedraza, Máquinas de amar, 1998) 


\section{INTRODUCCIÓN}

No han proliferado en España los estudios sobre las audiencias del cine ni las actitudes históricas de los espectadores $y$, menos aún, sobre los públicos femeninos: los juicios y gustos de las mujeres que desde siempre - ¿quizá con menor frecuencia que los hombres?- han ido al cine 1 . La historiografía y la teoría cinematográfica feminista tienen, de hecho, un importante filón en los fondos menos prestigiosos de archivos y hemerotecas -revistas "femeninas", gacetillas publicitarias, manuales de conducta...-, en la metodología etnográfica y la historia oral -las entrevistas con testigos vivos- para afrontar en el contexto hispano investigaciones sobre la relación de las espectadoras con el cine -con las películas y con la institución cinematográfica-, que examinen no sólo las formas en que desde la representación cinematógrafica se construye e interpela al espectador/a, sino las respuestas de los públicos concretos en condiciones históricas concretas, las estrategias de la industria y de la institución -si las ha habido- para atraer a la(s) audiencia(s) femenina(s), todo ello desde un conocimiento necesario de las prácticas culturales, de ocio y de consumo que han podido permitirse las mujeres a lo largo del pasado siglo, según su edad y clase social, su hábitat rural o urbano, estado civil, independencia económica o, en fin, las limitaciones impuestas a su acceso a los espacios públicos y al disfrute del "tiempo libre"2. Pensemos que la imagen de la proletaria Cecilia (Mia Farrow), en La rosa púrpura del Cairo (Woody Allen, 1985), viendo una y otra vez, en soledad, la misma película era poco probable en la España de antes y después de la guerra civil, donde "una chica -según constata Carmen Martín Gaite $(1987,191)$ refiriéndose a los años 40- nunca iba sola al cine, de la misma manera que tampoco entraba sola en un café. Ir al cine era un ritual de grupo"s. Igualmente, puede que no fuera ajena a la experiencia de las universitarias con pocos recursos en los años 60 la situación de esa joven doctora protagonista del cuento de José María Merino, El niño lobo del cine Mari, "poco aficionada al cine, sobre todo por una falta de costumbre que provenía de su origen rural, de un internado severo de monjas y de una carrera realizada con bastantes esfuerzos y poco tiempo de ocio". Sólo ocasionalmente, "como ejercitando un obligado rito colectivo", asistía a "la proyección de alguna película que la publicidad o los compañeros proclamaban como verdaderamente importante" (Merino, 1982, 210).
En la consolidación del cine como espectáculo popular y de masas tuvo sin duda un papel de cierta relevancia el público femenino (no sólo el iletrado, aunque fuera mayoría), cuya asistencia al cine en compañía de niños o adultos ${ }^{4}$ y cuya familiaridad con las revistas cinematográficas ilustradas creció imparablemente desde los tiempos del "Llévame al cine, mamá" -"picante" canción popularizada en el sainete La gente seria (Arniches y García Álvarez, con música del maestro Serrano, 1907)- hasta 1935, cuando dos películas españolas coinciden en presentar en clave cómica a sendas jóvenes fascinadas por la pantalla y el glamour de sus estrellas. En Don Quintín el amargao (Luis Marquina, 1935), Felisa (Luisita Esteso), la hija de un peón caminero bruto y borrachín con el que vive en una casa al borde de la carretera, se distingue por su afición al cine ("¿Es usted cinemática?", le pregunta un visitante al oirle decir: "mi tipo es Gary Cooper"), adquirida no tanto viendo películas como viendo revistas, alimento de fantasías compensatorias y estímulo para su imitación, convertida en ridícula mueca, de las poses de Greta Garbo en La reina Cristina de Suecia (Mamoulian, 1933)5. Más original, El Gato Montés, primera película de la directora Rosario Pí, muestra a Solilla (Mapy Cortés), la jovencísima criada del cortijo que dice no haber nacido ni para casarse ni para fregar platos, sino "para peliculera"6, dispuesta a hacer una prueba cinematográfica "en bañador" hasta que encuentra en un camino solitario al bandido apodado "el gato montés", que la sube a su caballo para cumplir con más presteza un encargo que salve a su amada. Solilla pasa del miedo al entusiasmo y a la publicidad del cine nacional: "!Dios mío! -exclama mirando al espectador- ¡Yo a caballo y con un bandolero! ¡Eso sí que es una película!". ¿Hasta dónde llegó el entusiasmo del público femenino y cómo asume las escasas posibilidades de intervención creativa en un país en el que sólo cabe citar siete nombres de directoras de cine hasta 1980? ¿En qué medida la crítica, los exhibidores y la industria del cine español tuvieron en cuenta a las espectadoras antes y después de la guerra civil? La estudiosa Jo Labanyi sostiene que "en la España de los años cuarenta como en otras partes el público cinematográfico era mayoritariamente femenino" (2002, 42), pero éste es un supuesto, repetido también para otras cinematografías (Loyo, 2002, 19), que aún está por demostrar?. Cabría preguntarse, de todos modos, si películas como El escándalo, La pródiga, El clavo, La fe o Pequeñeces, de inspiración literaria e importante éxito en los años cuarenta, pudieron funcionar no sólo como "adap- 
tación" hispano-católica de los melodramas de Hollywood, sino como un equivalente de los llamados woman's film ${ }^{8}$. En cuanto al insólito protagonismo femenino de los filmes del ciclo histórico - La princesa de los Ursinos, Locura de amor, Doña María La Brava, Reina Santa, La duquesa de Benameji, Agustina de Aragón, La leona de Castilla...-, ¿es factible pensar que fueran títulos destinados a una audiencia mayoritariamente femenina, formada quizá por las viudas y huérfanas de los vencedores de la guerra civil, a las que se adoctrina persuasivamente para soportar las penurias de postguerra y velar por la memoria de los varones muertos permaneciendo fieles a sus ideales? ${ }^{9} \mathrm{Y}$ otro interrogante, al que volveré: ¿acaso acabaron viendo más cine español que los hombres las niñas y mujeres de postguerra debido a que, por su ortodoxia moral, estuvo bien representado en las programaciones de los círculos que ellas frecuentaban: desde el colegio de monjas al cine parroquial o los centros de la Sección Femenina?

Para responder, siquiera parcialmente, a estas preguntas y a otros temas que nos inquietan (¿cuál fue la presencia del público femenino en cine-clubs y salas de arte y ensayo? ¿contribuyeron las espectadoras al éxito de las películas del "destape"? ¿se reconocieron en la "cosificación" de la mujer típica del cine de los 70? ¿cómo fueron recibidos los primeros filmes de las cineastas Pilar Miró, Cecilia Bartolomé y Josefina Molina? ¿Interesó el debate sobre la representación fílmica y televisiva a los discursos feministas de la Transición?) la crítica cinematográfica "seria" apenas ofrece datos ni ayuda. Abrumadoramente masculina, por quienes la han cultivado $y$, sobre todo, por su enfoque androcéntrico ${ }^{10}$, la crítica ha venido sustentando su análisis en un concepto de espectador neutro, desgenerizado, impermeable a la diferencia sexual de la

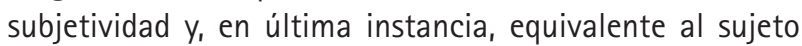
masculino. Sin embargo, esta posición es a todas luces insuficiente y decididamente problemática en el contexto español, marcado por los largos años del franquismo en los que, además de suprimirse "esta inmundicia moral y pedagógica que se llamaba 'coeducación', en palabras de Adolfo Maillo, Inspector de Primera Enseñanza en 1943" (Escabias Lloret, 2001, 70), todo el proceso de socialización de los individuos estaba fundado en una rigurosa división binaria de identidades de género, de sus atributos y roles (lo que no quiere decir que la segregación hombre/mujer en la existencia social "triunfase" siempre en la existencia psíquica). Por ello, y sin la menor intención de reforzar dicho binarismo de género, me parecen muy útiles las observaciones de Teresa de Lauretis:

Pero los espectadores entran en el cine como hombres o como mujeres, lo que no quiere decir que sean simplemente masculinos o femeninos, sino más bien que cada persona va al cine con una historia semiótica, personal y social, con una serie de identificaciones previas a través de las cuales se ha sexualizado en cierta medida. Y puesto que él o ella son sujetos históricos, que se ven continuamente envueltos en una multiplicidad de actividades significativas, que, como el cine o la narración, descansan sobre y perpetúan la distinción fundadora de la cultura -la diferencia sexual-, las imágenes cinematográficas no son para ellos objetos neutros de una percepción pura, sino "imágenes significantes", como observó Pasolini; y significantes en virtud de su relación con la subjetividad del receptor, codificadas con un cierto potencial para la identificación, situadas en una cierta posición con respecto al deseo. Llevan en sí, incluso al inicio de la película, una cierta "posición de la mirada" (1984, 229-230).

$$
* \quad * \quad *
$$

Este largo preámbulo quiere servir de pórtico a nuestra propuesta de escuchar la voz de las escritoras españolas en cuanto espectadoras de cine. Aunque pocas hayan ejercido la crítica propiamente dicha, las escritoras se han ocupado del cine como tema y estímulo creativo de ensayos, novelas, poemas, $y$, dentro de la excepcionalidad de su situación, dado su origen social mayoritariamente burgués $y$, sobre todo, la singularidad de ser mujeres con una vocación profesional, el testimonio de su experiencia vital y de sus observaciones, transfiguradas en la escritura, puede ser un punto de vista valioso para el estudio de la relación espectadora/cine en el contexto español, ya que la literatura es un espacio en el que quedan representadas las dos nociones que distingue Annette Kuhn (2002), la de "audiencia social" (los públicos ya divididos a priori en categorías de género, clase, etc., a los que se dirige la industria y la institución) y la de "espectador/a" (como "posición subjetiva" que interactúa con los textos). Ambas problemáticas convergen porque, de un lado, las autoras mismas y el universo ficcional que construyen pueden dar cuenta, de forma realista, paródica o crítica, de las conductas y vivencias de un grupo social, con sus hábitos y condicionantes ideológicos - pienso, por ejemplo, en las 
jóvenes espectadoras de Entre visillos (Carmen Martín Gaite, 1957), o en las esposas de la burguesía catalana que comentan El último tango en París (B. Bertolucci, 1972), en Tiempo de cerezas (Montserrat Roig, 1977); de otro lado, el conjunto de referencias al universo del cine, a las películas, personajes, estrellas o paratextos filmicos... que hallamos en poemas o en novelas de fuerte transfondo autobiográfico muchas veces, no sólo deja constancia de las variables del impacto social del cine o de los modelos que seducen a cada generación de espectadores/as ${ }^{11}$; también ilumina aspectos de la subjetividad y el deseo de los personajes, narradores/as y autoras, sacando a la luz los complejos mecanismos psíquicos -identificaciones, rechazos, desdoblamientos- que están involucrados en el placer de ver cine (de ficción narrativa).

En este sentido, podemos anticipar que la relación espectadora/filme suscita no pocas veces cierta conflictividad interna, especialmente entre las autoras de la segunda mitad del siglo XX. Aunque fascinen las imágenes, los modos de mirar de la cámara o determinadas estrellas (masculinas y femeninas), cuando las escritoras invocan desde la literatura el medio cinematográfico no pueden ignorar el peso de las representaciones de la "mujer" que perpetuan estereotipos de la feminidad/masculinidad y paradigmas de relación sentimental (heterosexual) que ellas cuestionan en su vida y en su escritura, rechazándolos como referentes válidos de la supuesta identidad de las mujeres o, al menos, de la propia realización personal. De igual modo, las posiciones narrativas "femeninas", tal y como se han codificado en muchos títulos del cine hegemónico (pasividad, masoquismo, secundariedad o el ambiguo poder de la vamp) resultan bastante insatisfactorias para las espectadoras literarias ${ }^{12}$, lo que origina habitualmente el desplazamiento de los lugares de identificación ("Hemos navegado con Gregory Peck a bordo de Pequod -escribe Susana Fortes $(2002$, 28)- persiguiendo una venganza blanca llamada Moby Dick. Hemos luchado contra los peores temporales, codo a codo, con piratas rudísimos e inolvidables..."; menos frecuente, a la inversa: en Julia, de Ana María Moix (1970), los hermanos de la protagonista representarán, jugando, papeles femeninos). 0 también desdoblamientos del yo para ocupar tanto posiciones masculinas como femeninas (la protagonista de Tiempo de cerezas imagina un filme en el que ella es, a la vez, el héroe-Natalia y la amanteNatalia) y reinterpretaciones, contralecturas, revisiones de ciertas películas emblemáticas, como la que hace Lidia Fal- cón en sus memorias, La vida arrebatada, al evocar en uno de los capítulos ("El baile de Escarlata O'Hara") los bailes del Casino Militar de la Barcelona de 1950 y su asistencia al estreno de Lo que el viento se llevó (Víctor Fleming, 1939) ("¿cómo debía ser un baile de sociedad, de la buena sociedad, sino una copia del baile de Lo que el viento se Ilevó, que era el baile más famoso del mundo?"). Su entusiasmo adolescente "con la romántica historia de amor de Escarlata, con las peligrosas aventuras que yo misma hubiera deseado vivir, con la excitación que me alteraba el pulso cada vez que veía a Clark Gable" (Falcón, 2003, 37-38) halló eco en la opinión común y en los elogios de la prensa, pero no en su madre, la escritora Enriqueta O'Neill, que se atrevía entonces a descalificar la película por su machismo y exaltación del racismo; juicio desconcertante, para la hija, aunque "inapelable", que Falcón reconoce haber tardado en compartir ${ }^{13}$.

Al interesarnos por la huella que ha dejado el cine en la obra de algunas escritoras españolas del siglo XX no pretendemos en absoluto segregar su discurso de la "raíz principal" que nutre el estudio de "los escritores/as y el

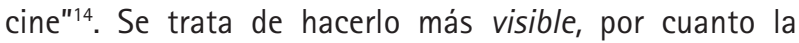
pereza crítica y los cuantiosos ejemplos de cinefilia entre los escritores varones tienden a relegar a un segundo plano aportaciones notables de autoras como Emilia Pardo Bazán, Rosa Chacel, Carmen Martín Gaite o Ana María Moix. Y se trata de averiguar qué aspectos, géneros y motivos cinematográficos están más presentes en sus obras, vinculándose a otras preocupaciones de su literatura -la afirmación personal, con sus miedos e incertidumbres, las fallas de las relaciones erótico-sentimentales, la relación entre sexualidad y poder, la amistad entre las mujeres, el compromiso político o la necesidad de revisar muchos discursos culturales en cuanto mecanismos de dominación social. No es monocorde ni rígido el punto de vista que del cine ofrecen las autoras que vamos a considerar -imposible en personalidades literarias tan distintas-, pero quizá por la forma menos libre en que han disfrutado el cine algunas de ellas, por las limitaciones del discurso fílmico en la plasmación diversificada del deseo y por el hecho, ya señalado, de no haber ejercido sistemáticamente la crítica, su cinefilia rara vez se manifiesta -ni siquiera en poesíacomo obsesión, fetichismo o mitomanía, tan frecuentes en los personajes-espectadores de la literatura masculina. $Y$ no es extraño tampoco que la incorporación del cine como experiencia y como referente cultural adopte la forma de la 
reflexión crítica mucho más que la de una erudición para disfrute de expertos cinéfilos.

En el sugerente libro titulado Gente en el cine, Anne y Joachim Paech constatan que "debemos a la literatura conocimientos esenciales acerca de la historia cultural de la sala de cine como lugar de experiencias" $(2002,14)^{15}$. Y de hecho, esta temática es recurrente, como se sabe, en la obra de Juan Marsé, Terenci Moix, José María Conget o Sánchez-0stiz, asociada no pocas veces a la rememoración de la infancia y juventud. También Esther Tusquets, en sus recientes memorias, Habiamos ganado la guerra, habla de una infancia ligada al cine, puerta abierta a la fantasía, como los libros, cuya trascendencia piensa que apenas pueden comprender "los jóvenes de hoy, que disponen de vídeo, televisión, internet" (Tusquets, 2007, 23-24). Como tantos que han dejado constancia de las salas de cine que "amaron" (Marí, 2003, 140), la autora cuenta cómo desde el balcón de su casa natal en Barcelona asistió "incrédula y emocionada" a la construcción del cine Alexandra:

Vi cómo terminaban las obras, cómo adornaban la fachada con luces y oropeles. Y alli estaba yo, la tarde de la inauguración, muy pegada a tía Blanca, una mujer todavía joven, todavía hermosa [...] allí estaba yo, un vacío en el pecho y la mirada extasiada, mientras se atenuaban despacio las luces rosadas que brotaban de unas conchas de oro y dejaban por fin la sala en la oscuridad, y el inconfundible rugido del león de la Metro anunciaba el comienzo siempre renovado del milagro.

Gozosa expectación infantil que encadena sin advertencia con una estampa mucho más sórdida:

Milagro que compartía con mi primo Bubi, cinco años menor que yo, las tardes de los sábados, sólo ensombrecido por el temor de que, y esto ocurría desde muy muy niña y con cierta frecuencia y nunca lo compartí con nadie, el vecino de la butaca contigua, en la oscuridad de la sala, iniciara sus manejos: la pierna muy pegada a la mía, la mano aventurándose por mi falda, intentando incluso, a veces, introducirse entre mis muslos, acariciando el pedazo de mi muñeca donde la blusa se abría antes de llegar al botón que cerraba la manga. $Y$ yo esquivándole, replegándome en mi butaca, apartando una y otra vez su mano, asustada y asqueada, pero sin decir palabra, convencida de que, si Blanca lo descubría, iba a armar un escándalo de tal magnitud que se pararía la proyección, lapidarian al culpable antes de que se pusiera a salvo y yo moriría de vergüenza (24).

\section{Pardo Bazán y las escritoras de vanguardia}

A Emilia Pardo Bazán le cabe en nuestro país "el mérito de haber sido uno de los primeros, si no la primera, en otorgarle al nuevo invento la capacidad para crear obras de $\operatorname{arte}^{116}$. Observadora atenta del progreso científico, la escritora gallega tuvo ocasión de conocer toda clase de espectáculos visuales -cineoramas, panoramas, dioramascuando asistió a la Exposición Universal de Paris de 1900, enviada por el diario El Imparcial, y ese mismo año escribe sobre el cinematógrafo en su sección "la vida contemporánea" de La llustración Artística, tema al que volvería en varios artículos más hasta su muerte, en 1921. Como tantos, puso reparos en principio al nuevo "juguete de la ciencia" -por el parpadeo y el temblequeo de las imágenes-, "juguete de niños", dirá, "reñido con el arte", pero en 1908 supo celebrar la expansión del cinemátografo "hasta en las más apartadas aldeas" mostrando incluso un sorprendente conocimiento del cine de la primera época al dar su opinión sobre los dos grandes tipos de filmes que cabía diferenciar dentro del binomio ficción/realidad. Ante las "escenas compuestas artificialmente", con sus pueriles argumentos melodramáticos, se muestra desdeñosa, aunque glosa con maestría un buen puñado de géneros y emprende "serias reflexiones" sobre el público, abarrotado de niñas y niños, que tanto los aprecia; en otro nivel quedan sus películas preferidas: las "vistas de la realidad" a lo Lumière $^{17}$, nada extraño en una escritora partícipe del ideario naturalista y burgués de la representación, que atribuye al realismo (veraz) de la imagen cinematográfica un valor estético nuevo que no dejará nunca de ensalzar, cifrando en ello y en la "imprensión de realidad" (lo verosímil) las ventajas del cine sobre el teatro ${ }^{18}$. Ya en 1915, poco antes de que Federico de Onís y Alfonso Reyes comiencen sus críticas "intelectuales" sobre el cinema, primero en la revista España y luego en El Imparcial, también cuando los escritores y artistas europeos empiecen a pensar el cine como arte, la autora de La cuestión palpitante se pronuncia en el mismo sentido, pero esta vez a propósito de una película de argumento: la famosa superproducción histórica, de la Italo Films, Cabiria (Giovanni Pastrone, 1913-1914). Como advierte Luis Miguel Fernández $(1997,108)$, en sus 
elogios pesaban la colaboración del poeta D'Annunzio, la semejanza argumental con Salambó, de Flaubert, la exactitud arqueológica en la reconstrucción de la época romana, pero también la grandiosa espectacularidad visual a la que no fue ajeno Segundo de Chomón. Era muy poco conservador el punto de vista de una Pardo Bazán fascinada con la veracidad del cine-atracción -los elefantes que cruzan los Alpes, el incendio de las naves, la erupción del volcán- y bastante sensible a los atractivos masculinos, cuya corporalidad visibiliza con sus comentarios:

[...] hay que añadir que en Cabiria se ve la mano del gran artista, y que también en las películas hay clases, jvaya si las hay! "Cabiria", además de arte, tiene su color científico.

Los detalles se ajustan a las rigurosas exigencias de la arqueología y la etnografía, y los tipos son cual los pudo soñar un pintor. Actores y actrices fueron elegidos según la etnografía lo requiere, y el negro Maccite (Maciste) es un ejemplar de humanidad que merece ser fundido en bronce. Hay un Escipión, figura de busto o medalla latina, un hombre como se ven aun muchos en Italia, envuelto en un manto blanco, que impresiona, porque sugiere la idea de que Escipión realmente sería asíi ${ }^{19}$.

No menos interesante resulta el que fue quizá su último artículo sobre asuntos de cine. "De películas" se publicó en el número especial de La esfera cinematográfica, dedicado a la temporada 1920-21 del "Programa Ajuria", y lo primero que llama la atención es la imagen que ofrece de ella misma como visitante asidua, ya en la vejez, de las salas de cine, al igual que lo serian años después Azorín o Rosa $\mathrm{Chace}^{20}$. Aparte de algunos certeros comentarios sobre las malas traducciones de los intertítulos y el lento desarrollo del cine español, el texto se centra en los melodramas sentimentales de corte romántico que, bajo la herencia de Griffith, se estaban consolidando en la producción norteamericana de la segunda década del siglo $\mathrm{XX}$, a la vez que surgian las primeras figuras del star-system, entre las que brilló Mary Pickford (la "novia de América"). Películas edificantes, protagonizadas por el estereotipo femenino de la ingenua (frente a la vamp), con pobres huérfanas acosadas por el infortunio, una inocente e idealista visión del amor y el no menos elemental maniqueísmo; películas pensadas ¿para una audiencia femenina? Pardo Bazán habla de "mujeres que lloran o se baban de gozo maternal" ante el niño que aparece en la pantalla "como si lo tuvieran en brazos y pudieran comérselo a besos", pero, en general, describe al público afecto a las intrigas emocionantes del cine como "un sujeto bonachón de corazón tiernísimo", compuesto no por artistas refinados, sino por "gente sencilla y predispuesta a la risa fácil y a la compasión vehemente; que se enternece ante la desdicha ajena y goza cuando los expósitos encuentran a sus padres, cuando los injustamente acusados son rehabilitados $y_{\text {, en }}$ suma, lo cifra todo en la lucha de buenos y malos" (Pardo Bazán, 1920/2005, 159-160). Cuando se están formando las convenciones del cine dominante, la escritora toma buena nota del lugar protagonista que en estos folletines tienen las mujeres -más, desde luego, que en los seriales de aventuras y en el western-, como soporte de amoríos y emociones que jugando la baza de su belleza y juventud las colocaba en una ambigua posición, entre el candoroso infantilismo y el objeto del placer visual. Al decir de Pardo Bazán, entre los elementos de emoción y sentimentalidad más efectivos en el cine estaban los perros, los niños (y niñas) y las muchachas:

Otra fuente de sentimentalidades son las muchachas [...] Las películas de amor se prestan al lucimiento de las actrices bellas y jóvenes (o que lo parecen, que viene a ser lo mismo) mujeres de cándida fisonomía, de abundante y rizada cabellera sombría o rubia, de ojos inocentes y grandes, de delicado perfil y manos como jazmines; las Margaritas Clark, las Mary Pickford, las Paulinas Frederick. Con solo presentarse con una dulce sonrisa o una actitud finamente triste, las damitas jóvenes del cinematógrafo consiguen lo que quieren; el gentío se enamora de ellas de un modo honesto, platónico y generoso, y con enamoramiento que dura exactamente tres cuartos de hora...

[...] Y no dejan de interesarnos, con el mismo interés que suscita un folletín, las aventuras y desventuras de las Fifis, Butterflies, Lydias, Amys, Anitas, Fantoches, Blanca Nieves y demás ingenuas que encuentro en el Programa Ajuria. Son todas una misma niña delicada y candorosa que ante el peligro y la desgracia se hace fuerte y sabe defender su dicha ${ }^{21}$.

Desde su condición de aristócrata e intelectual culta, la escritora vuelve a establecer una diferencia entre la aportación más artística del cinema -ligada a los elementos de realidad-y los ingredientes literarios dramático-folletinescos. Considera que "no son arte los dramas, ni las comedias rebosadas, ni los sainetes sin gracia, ni las óperas mediocres plagadas de reminiscencias" 22 . Pero no es la suya 
una actitud de menosprecio elitista ante lo que llama "el sentimiento de las multitudes", ante el modo de explorar -y explotar- las emociones que caracteriza al incipiente melodrama de Hollywood; lo que reclama es su confluencia con un bien hacer artístico, en los temas, la ambientación, la poesía de las escenas, bien hacer que sí encuentra en uno de los títulos que prefiere: la adaptación de Madame Butterfly, dirigida por Fritz Lang (Harakiri, 1919).

Una de las escritoras que pudo conocer las películas y el ambiente de los cines a los que alude Pardo Bazán fue Rosa Chacel. En Barrio de Maravillas, bildungsroman autobiográfico que publicó en 1976, reconstruye precisamente los años en que la autora vallisoletana vivió en Madrid, en torno a la Primera Guerra Mundial, mediante las vivencias de dos protagonistas adolescentes, Elena e Isabel, contempladas en su marco familiar y vecinal, en sus aspiraciones, estímulos y resistencias que darán forma a su temprana vocación artística (Kirkpatrick, 2003, 59). En el amplio abanico de referencias culturales de la novela -las artes plásticas, la música y la literatura-, también el cine ocupa un lugar destacado tanto por la configuración estructural de la obra en secuencias de corte cinematográfico (Rodríguez-Fischer, 1993, 29) como por los discursos que subrayan las raíces primeras de su impacto estético, la mención de varias salas de Madrid -el Teatro-Cine Príncipe Alfonso, el modesto Pardiñas, el incendio del Cine del Noviciado-, y de géneros o estrellas que atraen a los personajes. El monólogo interior de Isabel expresará, por ejemplo, su emoción estética ante la "nueva belleza" del cinema, a la vez que sus dificultades -de clase y de género- para disfrutarla:

[...] sólo había una gran atracción, pero lejana -inada en el barrio!- y cara, el Príncipe Alfonso, donde iban las chicas a la moda, y los chicos, los que fluctuaban en sus predilecciones: demasiado ingenuos los cow-boys, demasiado enchisterado Max Linder ... Las italianas bellas, irresistibles, intimas, próximas sobre todo... iProximidad!... Una proximidad tan cierta que es ya posesión. La belleza de un ser humano y la belleza de su gesto, de su situación, de lo que en la vida real está siempre lejos, inalcanzable a veces y allí tan próximo, tan acariciador [...] Y las cosas lejanas en el tiempo, los carros romanos, el circo, los gladiadores... En fin, lo infinitamente posible, pero por desdicha lejos, a gran distancia y como acorazado en su carácter de lujo, dificultado por la necesidad de compañía: todo ello dando como resultado la infrecuen- cia. El asistir de visita, cuando lo deseable era ir y quedar alli... (Chacel, 1976, 319. El subrayado es nuestro).

Elena e Isabel viven en un barrio de clase media baja, de "pobretería disimulada", como dice Chacel en sus memorias (Desde el amanecer), rodeadas de mujeres trabajadoras e ilustradas; ellas mismas asisten, por ser gratuita, a la Escuela de Artes y Oficios y se preparan al final de la novela para ingresar en la Academia de San Fernando. Les apasiona el Museo del Prado, la ópera, las ilustraciones del Infierno de Dante y el cine, gran símbolo de la modernidad tecnológica y estética. Pero, como observa Kirkpatrick, "los mensajes que este universo estético les trasmite a ellas son tan ambiguos como los que les ofrecen sus modelos de feminidad" $(2003,73)$, por cuanto las creaciones que admiran, en el marco del esteticismo modernista, reproducen esquemas culturales que definen a la mujer como inferior. Entre el ideario doméstico del ángel del hogar y el discurso intelectual dominante que considera incompatible la vocación artística y la feminidad, prejuicio que comparten los compañeros varones de las dos jóvenes, Elena e Isabel intentan afirmar su yo intelectual, emocional y creativo, reto lleno de tensiones que afrontan a lo largo de la novela, siendo uno de los momentos clave el diálogo en el que, confusamente todavía, choca su propio deseo (para el que apenas hay referencias) con las pautas de seducción y contacto físico impuestas por la literatura y el cine:

- ¿Eso es que me quiere? El otro día me cogió la mano y me mordió un dedo. ¿Eso es porque me quiere?

-Claro ¿por qué va a ser?

-¡Me harta ese asunto del amor! Tú lo entiendes porque lees novelas que están llenas de eso: por eso no me gustan. Me cansa leer, prefiero dibujar...

-[...] Lo que no entiendo es que te harte la idea del amor y te entusiasmes con lo que ves en el museo. ¿Tú crees que eso existiría si no fuera por amor? [...]

-Debe de ser verdad, debes de tener razón; por eso me revienta hasta en el cine. A ti te gustan las películas de amoríos, a mí las de aventuras, las de caballos que corren y vaqueros que echan el lazo. También me gustan las de detectives: a ti sólo las de Francesca Bertini.

-No sólo esas, pero sí es mi preferida. ¡Tiene una elegancia! No sólo en el vestir sino en los movimientos, en las actitudes. Felisa me ha hecho observar un detalle, en las escenas amorosas ella siempre se mantiene en una postura no precisamente altiva, pero sí situándose en una posición en la

ARBOR Vol. 187748 marzo-abril [2011] 345-370 ISSN: 0210-1963 
que el amante esté como ascendiendo hacia ella. Siempre, cuando llega a besarla...

-A mí me revienta eso de los besos [...] Eso de que se besen en la boca me revuelve el estómago. Ya sé que no se besan, pero lo parece. ¿Y qué me dices de algunos versos que he leído en los que hablan del deseo de besar sus labios?

-Empiezo a creer que yo soy mucho más idiota que vosotras $y$, probablemente, que todo el mundo, porque tú sientes esa repugnancia y lo dices; yo, si lo pienso bien, también me repugna, pero lo he leído y como lo que he leído dice que es maravilloso no soy capaz de pensar diferente de lo que he leído. ¿Es estupidez o es fe? No sé, ya lo veremos... $(250-251)^{23}$.

No será la última vez que dos personajes femeninos confronten sus gustos ante figuras que funcionan como "ideales del yo", héroes o heroínas, estrellas, pero también ciertos géneros y estilos que tanto la institución cinematográfica como la sociedad suelen considerar representativos de cada uno de los polos de la diferencia sexual. Isabel forja su identidad de género proyectándose en comportamientos supuestamente masculinos, en modelos "impropios" para una mujer, como los que ofrecian los héroes del western y, en menor medida, los seriales de aventuras policíacas. Con Laura Mulvey (1975), diriamos que, para obtener placer viendo cine, "masculiniza" su mirada, al sentirse implicada en peripecias de conquista o investigación antes que en asuntos de amor, considerados más atractivos para las mujeres ${ }^{24}$. Elena, en cambio, parece encontrar en la diva Francesca Bertini (Idilio trágico, Assunta Spina; La dama de las camelias) y en las escenas prototípicas de su relación con los hombres un modelo femenino positivo, atrayente por su refinamiento y elegancia, porque encarna también -en apariencia- una sexualidad libre y poderosa. Como ocurrirá después con las "malas" del cine negro, la fuerza que se desprende del impacto visual de la estrella pesa más que el destino trágico de los personajes que solía interpretar entre 1912 y 1916, y que acababan sus días en la cárcel o muertos por enfermedad, suicidio, autoinculpación; sacrificados, en definitiva, a los intereses del orden burgués patriarcal. En las elecciones de Isabel y Elena hay, sin embargo, otro aspecto digno de atención, ya que Rosa Chacel está evocando un debate estético-cultural en torno al cine que se abre paso con los movimientos de vanguardia y que Guillermo de Torre plasmó en el poema "Friso ultraísta" (1919), donde exaltaba la modernidad de los filmes norteamericanos -los vaqueros, las persecuciones $y$, pronto, los grandes cómicos del mudo- en contraste con los decadentes dramas europeos:

$\begin{array}{cc} & \text { pasiones auriferas } \\ & \text { y complots sangrientos. } \\ \text { ¡HURRA POR EL } & \text { ¡Un haz de fibras convulsivas, } \\ \text { FILM } & \text { culmina en vértigo dinámico } \\ \text { NORTEAMERICANO! } & \text { la epopeya de la objetividad! }\end{array}$

Franjas multicromas se expanden: (A un ángulo penunbroso

Persecuciones. Incendios

Tiros. Salvamentos

la incolora delicuescencia

-besos, trucos y claros de lunadel film italo y francés).

Aunque todavía es poco conocida la obra de muchas escritoras del período anterior a la guerra civil (Ruiz Guerrero, 1997, 154-157), han crecido notablemente los estudios sobre las autoras vinculadas a la vanguardia y el descubrimiento de nuevos textos que muestran hasta qué punto compartieron las reivindicaciones de la "mujer nueva", inquietudes políticas progresistas y un aprecio por los valores de la modernidad que hallaban fundamento estético en el cinematógrafo. José María Conget inicia la "primera parte" de su antología poética, Viento de cine (2002), con un texto de María de la 0 Lejárraga que viene a describir la emoción de una turba de chiquillos ante el espectáculo de "La linterna mágica" (Flores de escarcha, 1900). Y recoge también algunos poemas que dedicaron al nuevo arte Lucia Sánchez Saornil ("Cines", 1921), Concha Méndez ("Cinelandesco", 1928) y Carmen Conde ("Oda al Gato Félix", 1929; "El cine en la playa, 1934), representativos del espíritu de la vanguardia. Sánchez Saornil, feminista fundadora del grupo Mujeres Libres y la única poeta que militó en las filas del ultraísmo, es una de las primeras voces poéticas que toman el cine como estímulo de imágenes y metáforas relacionadas con el nuevo orden de la visión y sus simulacros ("La ventana pantalla cinemática/reproduce su película inmortal/en los espejos") o con la asimilación de la palabra a la sustancia expresiva del discurso fílmico ("A toda luz mis palabras-reflectores/proyectan en tus ojos/ un film sentimental") (Sánchez Saornil, 1996, 98). En el poema "Paisaje de primavera" (1925), lo poético tradicional se revitaliza al aunar naturaleza y técnica en la asociación /río-film/, convirtiendo las aguas en la gran pantalla que refleja un paisaje móvil ("Film de largo metraje/El paisaje en marcha./Los árboles se miran al espejo/cómo el viento los despeina" (104). Emociones muy distintas, de tedio y 
vacío, inspiran, en cambio, "Domingo", donde la soledad interior ("La ventana bosteza/en el fondo/cansada de mirar/ siempre el mismo paisaje/En el plano del alma/nadie pone su mano") no halla contento en la urbe ni en dominicales sesiones de cine popular:

$$
\begin{aligned}
& \text { En la ciudad } \\
& \text { la cinta cinemática } \\
& \text { desenrrolla su metraje } \\
& \text { No quiero } \\
& \text { no quiero } \\
& \text { Film para los horteras } \\
& \text { y las porteras (109). }
\end{aligned}
$$

El cine, como expresión del movimiento y el ritmo del mundo moderno, da vida a lo "Cinelandesco", título de uno de los poemas de Concha Méndez, que hace suyos un puñado de motivos familiares al imaginario de los poetas de "la generación del cine y los deportes". Se trata de un auténtico poema urbano ("Clamor de bocinas vírgenes/de palabras dislocadas;/de violines callejeros/entre un ritmo de pisadas") que yuxtapone breves imágenes a ritmo de jazz-band: la luz de los escaparates, los anuncios luminosos, el carrusel de la feria... hasta culminar en la fugaz estampa del balón que vuela en el Estadio (Conget, 2002, 82-83). Más emotivo ("humanizado", diríamos) es "El cine en la playa", el breve poema en prosa de Carmen Conde que reproducimos al comienzo de estas páginas y que se publicó en Júbilos, en 1934, libro prologado por Gabriela Mistral. Interesa destacar su indudable trasfondo autobiográfico, pues la autora ejerció en los años 30 como maestra, y la hermosa estampa de quien, rodeada de niñas, camina un día ventoso hacia el cine al aire libre, sintiéndose "fuerte como un árbol", feliz por la felicidad que brinda a las "hojas diminutas" que la rodean anhelantes (Conget, 127) 25 .

En un país más abierto a la creatividad femenina y con una industria cinematográfica más boyante podía haber prosperado la presencia activa de algunas escritoras en tareas de dirección -sólo las asumieron Helena Cortesina, en el mudo (Flor de España, 1921), y Rosario Pi, a comienzos del sonoro, la citada El gato montés y Molinos de viento (1937)- o, al menos, como guionistas, actividad más discreta que desempeñaron tanto Concha Méndez como, ya en el exilio, María Teresa León. El caso de María de la 0 Lejárraga, que aceptó eclipsar su autoría tras el nombre de su marido, Gregorio Martínez Sierra, es sintomático del papel discreto que asumieron las mujeres de la generación anterior -Lejárraga nació en 1874-, no importa que, en su caso, llegara a ser diputada socialista durante la República. Como dramaturgo prestigioso, Martínez Sierra viajó a HoIlywood entre 1931 y 1935 para colaborar en la realización de películas en castellano para la Metro y, más tarde, la Fox, compañía que lo nombró director de su sección hispánica, a pesar de que era un secreto a voces -recuerda López Rubio- que "no escribió un solo guión, porque no sabía hacerlo, del mismo modo que sus comedias las escribió en realidad su esposa" (Gubern, 1994, 199) ${ }^{26}$. Distinta fue la actitud de Concha Méndez, cuya implicación en el medio cinematográfico habría sido con toda seguridad más intensa en otras circunstancias históricas y sociales. Poeta y dramaturga, novia de Luis Buñuel cuando éste pensaba más en los insectos y en los deportes que en el nuevo arte, escribió sobre estética cinematográfica en dos artículos publicados en La Gaceta Literaria ${ }^{27}$, al tiempo que su teatro -por ejemplo, El personaje presentido-acusaba la influencia del nuevo lenguaje, como ha sido notado en varias ocasiones (Nieva de la Paz, 1993, 275-6). Con motivo de la filmación, en 1927, de su argumento Historia de un taxi, declaró: "Quiero ser, a más de argumentista, director, cineasta. $Y$ digo quiero ser porque aún no llegué a dirigir ningún film; no por falta de deseo ni de preparación para ello, sino por falta de capital. Esto aquí en España es un problema. Y más tratándose de poner capital en manos de una mujer" (Utrera, 2000, 80) ${ }^{28}$. Película hoy perdida, Historia de un taxi fue el primer título realizado por el sevillano Carlos Emilio Nazari para su productora "Film Nazarí". Aunque se hicieron dos pases privados, de los que hay testimonios elogiosos (Utrera, 82-85), no llegó a estrenarse comercialmente, en buena medida porque, a pesar de la apariencia de comedia frívola, el argumento del filme contenía ingredientes muy transgresores, al proponer un juego de travestismos y equívocos sexuales que no sólo desestabilizaban los roles de género, como en el teatro clásico, sino que insinuaban relaciones lesbianas ${ }^{29}$. Ya en el exilio, en México, otro texto de la escritora sirvió de base a la última película que dirigió Eduardo Ugarte, el filme de suspense Cautiva del pasado (Prisionera del recuerdo, 1952).

También en el exilio inicia María Teresa León una actividad cinematográfica que seguramente vio, junto con sus guiones de radio, como una ayuda para sortear las 
dificultades económicas de los primeros años de destierro. Estupenda cuentista ${ }^{30}$ y dramaturga preocupada por la renovación técnica y temática del teatro -en 1933 escribe la pieza vanguardista Huelga en el puerto, que surge tras su conocimiento del teatro y el cine soviéticos-, trabajó en el guión de Los ojos más bellos del mundo (Luis Saslavsky, 1943), al que siguió una versión de La dama duende (1945) de Calderón, igualmente filmada por el director argentino, que alcanzó un enorme éxito. Con Rafael Alberti, su marido, daría forma en 1947 al guión de El gran amor de Bécquer, de Alberto Zavalía (Mateos Miera, 2003, 297-309). Otras escritoras cuyo interés por el cinematógrafo habría que destacar son la novelista peruana Rosa Arciniega, inmersa en la vida cultural española durante los años de la República y autora de Vidas de celuloide: la novela de Hollywood (1935), Josefina de la Torre Millares, partícipe, con su hermano Claudio de la Torre, en la adaptación de doblajes de los estudios Joinville (Francia), o quienes escribieron en revistas de cine -a veces sobre las estrellas femeninas-, como Amparo Verardini, Marta Vergara o Josefina Carabias ${ }^{31}$. Sólo me detendré, sin embargo, en Rosa Chacel, la prosista de la generación del 27 en la que caló de forma más honda y permanente -no hay que olvidar su formación de Bellas Artes- el impacto del arte nuevo ("El cine es el alma en pena de un arte plástico. Es un arte plástico sin plasmar", se dice, cual grueguería ramoniana, en Estación, ida y vuelta). Si para los escritores de la vanguardia el cinema era exponente de un nuevo modo de visión y conocimiento de lo real, con ese entusiasmo de los orígenes, lo exalta Chacel en Barrio de Maravillas:

[...] la sensualidad suprema, la que se extiende o infiltra o se adueña palpable con el mismo poder de la mente y del sentimiento, la visión..., el cine. Las Indias inagotablemente descubiertas, lugar de emigración. Eldorado para todos los pobres y todos los ambiciosos..., plantío de ambiciones, muestrario de bellezas - sin canon- más bien instaurador, creador con el solo poder de su índice luminoso..., de su FIAT... El cine, la realidad en imágenes sin cuerpo, sombra y luz... silencio, esto es, atención. Atención sin pestañeo, abrir los ojos y ver..., ver velozmente porque pasa..., la imagen se escapa y no vuelve, pero se grabó suficientemente [...], su cadena es irrompible, llena toda la noche de la visión y la llena con las más extremadas escenas de amor o de muerte, clamando en el silencio... (154-155).
La cinefilia de la escritora vallisoletana dejó huella en su labor literaria desde sus primeras obras. Como en Estación, ida y vuelta (1927/1930) (Morris, 1984, 151-153), una novela autorreflexiva y metafictiva que conjugaba rasgos de la vanguardia poética española con elementos del modernism europeo, especialmente, la subjetividad de la narración que, en la obra de Chacel, queda a cargo de un sujeto masculino cuya peripecia y reflexiones acaban siendo la justificación misma de la escritura. Cuando este personaje narrador -travestismo de la autora que elude así, salvo en el prólogo, la voz femenina, sin tradición discursiva alguna como fuente de autoridad/objetividad- fantasea sobre su proyecto artístico, los escenarios y dramas en los que envuelve a sus personajes son pensados bajo la forma antirrealista de lo "cinematizable": acciones fragmentadas, huidizas, emociones que precisan, para plasmarse, de los recursos de montaje, planificación y trucos propios del cine mudo ${ }^{32}$. Por esta misma época escribió Rosa Chacel el cuento Chinina Migone, publicado en Revista de Occidente en 1928, cuya enigmática fábula anticipa en cierto modo la de otro cuento muy posterior, El niño lobo del cine Mari, de José María Merino, ya citado, al tiempo que confirma la tesis de Miran Hansen acerca de las posibilidades que el espectáculo cinematográfico abría a las mujeres (británicas) dándoles acceso a una esfera pública radicalmente nueva: "more than any other entertainment form, the cinema opened up a space -a social space as well as a perceptual, experimental horizon- in women's lives" $(1991,117)$. La historia de un matrimonio que "pierde" a su hija en el cine hablaba de la propia autora pero adquiría también una dimensión alegórica al convertir el nuevo arte en símbolo de la ruptura de dos generaciones y dos siglos separados de forma irreductible ${ }^{33}$. Así lo lamenta el padre, narrador del relato, hombre que pudo cortar las alas creativas a su esposa, cantante de ópera de valía, pero cuya hija se le escapa. Simbólicamente, la pequeña Chinina se había encerrado en un denso mutismo desde la niñez y se aísla más aún de la influencia familiar cuando descubre su elemento: el arte mudo. A partir de ahí se genera en el texto una proliferación de metáforas filmicas, como cuando el padre, con rencor, atribuye su pérdida a la aparición en la ciudad de "aquellos pálidos acuarios" que eran como "agujeros en la vida":

hervidero de las imágenes, de todo lo bullente, de todo lo que en silencio fraguaba su vitalidad, para un día saltar e invadirnos. Y la dejábamos acercarse a ellos porque en un 
principio no parecian temibles. La barraca atraía con su alegre órgano, y era tentador entrar a ver el nuevo invento. La ciencia moderna tenía alli su guarida de hechicera. No pudimos defenderla. Cuando la sacábamos de su mundo al nuestro, después de una pesca tenaz, la encontrábamos inadaptada y la soltábamos otra vez, por no anularla, por no verla deshacerse con nuestro contacto (84-85).

Sobre la estrella Janet Gaynor escribió Rosa Chacel en "Vivisección de un ángel" (La Gaceta Literaria, n. ${ }^{\circ} 44,15-$ 10-28), a raíz del estreno de la película Street Angel (El ángel de la calle, Frank Borzage, 1928), melodramática historia de amor entre un pintor ambulante y una joven que ha de prostituirse para sobrevivir, interpretada por la Gaynor y Charles Farrell, célebre pareja romántica del cine norteamericano del momento. "Nos apremia saber qué valor esencialmente cinemático tiene el extracto Jannet (sic). El auténtico 'Coeur de Jannet' que trasciende de sus tres filmes" ${ }^{\prime 34}$. Esta esencia la ve traicionada en El ángel de la calle por su "tóxico" argumento (que prostituye la ingenuidad virginal de la actriz) y por una puesta en escena realista y teatralizante, lo que le lleva a tomar conciencia de las desiguales posibilidades artísticas que tenían las estrellas masculinas y femeninas:

A primera vista, abominar de la fábula en un film puede parecer lo mismo que encontrar banales los temas frecuentes en el cine. No es eso. Charlot y Buster Keaton evidencian al mismo tiempo que su cinematismo el de sus argumentos. Es decir, no buscan un argumento más o menos adaptable a determinada posibilidad cinemática, sino que argumentan el cinematismo en sí. Tragedia de las estrellas hembras: valiosísimos entes cinemáticos carentes de mentalidad adecuada para realizarse sin ayuda (Pérez Merinero, 1974, 60-61).

La autora no aclara por qué las "estrellas hembras" no pueden realizarse sin ayuda o a qué deben sus carencias, si a la propia naturaleza femenina, como dirian los Marañón y Ramón y Cajal, o a la institución cinematográfica que, narrativamente, las colocaba a la sombra del héroe varón. Lo que sí echa de menos, con rotundidad, es la falta de actrices/estrellas femeninas creadoras de un "tipo" realmente autónomo, encarnación de un concepto, con personalidad y protagonismo equivalentes a los que alcanzaron un Chaplin o un Buster Keaton. No es extraño que el "templo cinemático" al que se acoge en este texto -coincidente con el catecismo vanguardista- invite a defenderse del que llama "filme monumental", sea "digno y concienzudo como Amanecer o falso y tóxico como El ángel de la calle", en aras de un collage abstracto de fragmentos visuales: "una columnata de rayas de pantalón, Willi Fritz, Menjou, grandes ventanas sobre el paisaje alegre; ojos de María Corda emparrados de rimmels, cabalgata de yeguas; torsos de Greta..." (62). Y no es extraño tampoco que le interesara, como desafío interpretativo, Un perro andaluz (1929), de Luis Buñuel. En el preámbulo a la edición española de su ensayo La confesión (1971), fechado en 1979, "confiesa" haber mantenido cierto debate con el director aragonés a propósito de esta película:

Se estrenaba Un perro andaluz y todos quedábamos deslumbrados, felices de encontrarnos en tal situación -porque eso era lo que pasaba, que estábamos en eso- y cada uno respondía a su modo. Fueron muchos los que respondieron asintiendo, entregándose, sin comprender gran cosa -o comprendiendo lo que había que comprender- otros, queriendo comprender más. Yo entre estos últimos.

Yo, con el mayor entusiasmo y, sobre todo, creyendo ver en aquello tan insondable profundidad, tan inagotable riqueza de sugerencias, de noticias no sospechadas antes, temí emitir un juicio exiguo o despistado y escribi a Buñuel una carta... Buñuel me inspiraba enorme admiración, pero no me intimidaba, era uno de los chicos de mi tiempo... (Chacel, 12).

Lamentablemente perdido el intercambio epistolar entre ambos, Buñuel contestó, al parecer, que Un perro andaluz "no significa más que una incitación al crimen y a la violación", lo que la hizo sentirse "profundamente ofendida porque aquel exabrupto demostraba que me creían lo suficiente pusilánime para asustarme de aquellos términos y volví a escribirle, diciendo que no me había impresionado y que, a pesar de aquellos temas tan interesantes, seguía teniendo empeño en hablar con él". De la charla que por fin tuvieron dice poco Rosa Chacel aunque se deduce el valor de su desafío, el triunfo de los argumentos del director y su propio repliegue, como mujer "de desprevenida franqueza", cabezuda, pero muy firme en su vocación (13).

Otro texto que merecería un análisis detenido es el capítulo que dedica al cine en los ensayos de Saturnal, escritos entre 1954 y 1960 . Haciendo suyo como emblema generacional el verso de Rafael Alberti "Yo nací, respetádme, con el cine" (Cal y Canto), irá desgranando las 
aportaciones del nuevo arte al mundo contemporáneo y su significado social y cultural a la altura del medio siglo -"esperanto que ha enseñado a ver y creer"; la forma que mejor representa "la epopeya sorda o violenta, cotidiana o insólita del héroe cualquiera" $(1972,104)-$, más o menos en la línea de las reflexiones que emprenden por entonces Francisco Ayala, desde 1949 (El cine. Arte y espectáculo) o, en España, Julián Marías ("El mundo cinematográfico", Objetivo, 4, 1954) e incluso Juan Gil-Albert (Contra el cine, 1955). Pero me interesa también la Rosa Chacel espectadora, tal y como se dibuja en los diarios que publicó en 1982, en dos volúmenes, con el título Alcancía, cuya primera anotación, fechada en Burdeos el 18 de abril de 1940, se cierra precisamente así: "El caso es que ya no estoy en París. Son las ocho, me voy al cine, a ver a Jean Gabin. jÉl es París! Un París que me fue siempre igualmente inaccesible..." [Alcancía (Ida), 1982, 14]. Era el principio de un largo exilio y, tras esta mención a Le récif de corail (Maurice Gleize, 1938) y, sobre todo, al actor francés que encarnaría al antihéroe desengañado existencialista ("He aquí el hombre!... con su cruz, con sus espinas, con su agonía"), no menudean las alusiones al medio cinematográfico hasta 1959, ya instalada en Río de Janeiro, cuando asistir al cine, incluso en sus viajes, se convierte en un hábito tan cotidiano y omnipresente como la lectura, necesario para su descanso y del que va dejando constancia crítica más allá del simple apunte de un título o de una valoración a vuela pluma. El repertorio de filmes mencionados a lo largo de los años y de las páginas del diario es amplísimo, como variada la tipología de géneros y estilos ${ }^{35}$, sin hacer ascos ni a la sala de un barrio ni a las sesiones del Museo de Arte Moderno, ni a las películas comerciales de entretenimiento ${ }^{36}$ ni al cine de autor, que irá asomando en los apuntes de los años 60 y 70 cada vez más como objeto de debate intelectual. Cierto que no le agradan ni Bergman ni Godard, aunque no deje de ver sus filmes ("Ayer Le petit soldat, tercer Godard que soporto. Extraño e incomprensible el entusiasmo de Pere Gimferrer por este tipo. Para mi gusto es un ejemplar del intelectualismo más empalagoso, amanerado, falso y rastreramente adulador de la modernidad", Vuelta, 13), pero merecen su atención Don Quijote (G. Kozintsev, 1957) ("que no es perfecto, pero que es el mejor que se ha hecho hasta ahora... Había uno olvidado los tipos nobles", Ida, 234); La dolce vita (Fellini, 1959); Cléo de 5 à 7 y Las criaturas (Agnès Varda, 1961 y 1966), El extranjero (Visconti, 1967), Belle de jour (Buñuel, 1967) ${ }^{37}$, If (Lindsay Anderson, 1968), Solaris (Tarkovski, 1972) ("que me traumatizó bastante... No sé qué pensar, tal vez haya alli cosas fundamentales, pero no sé si es que yo las pongo. Trataré de hacer que Javier Aguirre me busque una pista", 11-5-80, Vuelta, 396) y, sobre todo, Blow-up (Antonioni, 1968) ${ }^{38}$ o, como veremos, La prima Angélica (Carlos Saura, 1973). En una de sus estancias en España, Rosa Chacel es capaz de dejar a Francisco Ynduráin, Manuel Andújar y Rafael Conte porque le habian dicho "que daban La dentellière [La encajera, Claude Goretta, 1977] en un cine de extramuros, y no quería perderla..., y la vi y me gustó muy poco, aunque es buena, técnicamente muy buena" (Vuelta, 401). La visión de una película puede infiltrarse a veces en los sueños nocturnos de la autora, descritos o silenciados, según la privacidad de sus contenidos. Blow-up propicia un sueño de rejuvenecimiento ("la realidad persistente de esa juventud que pugna por levantarse de la charca de decepción y fracaso en que vivo", Vuelta, 70-75). Otros filmes y algún actor introducen la seducción -William Holden- 0 el erotismo, como su sueño con Mel Ferrer, que le lleva a explicar sus experiencias sinestésicas vividas en el cine más allá del placer escópico voyeurista ${ }^{39}$. Y también hay lugar para el rechazo de la degradante erotización del cuerpo femenino, enemiga, a su juicio, de la belleza. Así, al hablar del filme Esa clase de mujer (Sidney Lumet, 1959):

Dos películas que ya había visto... Lo tremendo fue que una de ellas era la de Sofía Loren y el chico Hunter [Ted Hunter]... Frecuentes grandes planos, en los que aparecen las dos cabezas -en interminables diálogos- grandes, grandes, enormes... ¡Qué reposo, qué nobleza, qué espiritu y qué vida en la cabeza de él! ¡Qué frivolidad en la cabeza de ella! Y el caso es que ella no es frívola. El tipo que le hacen adoptar la degrada: sus defectos están artísticamente acentuados por el maquillador... Le suben los ojos hasta las sienes, le aumentan los morros que, ya de por sí, tiene enormes y blandos, cosa que hace más visible la pobreza del maxilar inferior y le ponen en bandeja el tetamen, que brota en un tórax huesudo, abruptamente. Bueno, ni siquiera aquí quiero decir las cosas que pensé... Porque lo grave es que las cosas que todo esto pone en peligro son mucho más vulnerables que la geometria eucliniana $(/ d a, 243-4)$.

La propia escritora será consciente, sin embargo, de los prejuicios que a ella misma la condicionan a la hora de enfrentarse a la creatividad de las mujeres. Muy reveladoras me parecen las opiniones que vierte sobre la directora francesa Agnès Varda, cuya obra y personalidad le atraen 
indudablemente, a la vez que le desconcierta la nueva actitud de las mujeres artistas e intelectuales que ya no están marcadas por la minusvaloración de lo "femenino" en la que ella se formó:

Me gustaría escribir algo sobre la Varda, y si no lo hago -enteramente aparte las causas circunstanciales del presente; si es que le puedo llamar presente a la ausencia integral-, si no lo hago es por una especie de cobardía... No quiero dar categoria de fidelidad a un propósito, a esta obstinación en no hablar de cosas -más bien de obras- de mujeres. Fue, sin duda, en su principio, un propósito; me negué a admitir esa clasificación o agrupación por la feminidad de personas que no tienen ninguna razón para agruparse. Hoy las cosas han cambiado mucho y, sin embargo, me cuesta trabajo ponerme en paladín de damas. Es un sentimiento mezquino, mujeril. Sobre todo porque en la obra de Agnès Varda lo femenino es un elemento de creación y de especulación. En un arranque de hombría podría decir "Haré algo sobre Agnès Varda", pero si lo dijese y hasta si lo hiciese quedaría sin correr el riesgo de una actitud pública, porque, si la hubiera, ¿dónde lo publicaría? (Vuelta, 18-19).

\section{ESCRITORAS DE LOS PRIMEROS AÑOS DE POSGUERRA}

No gozaron de la misma libertad e independencia para frecuentar el cine la mayoría de las escritoras españolas de las dos generaciones siguientes que vivieron bajo el régimen y la censura franquistas: las narradoras y poetas formadas antes de la guerra civil -Dolores Medio, Carmen Laforet, Elena Quiroga, Elena Soriano, Concha Zardoya, además de Mercè Rodoreda ${ }^{40}$-, pero que, en su mayor parte, comienzan a publicar a principios de los años 50, o las autoras más jóvenes del medio siglo: Ana María Matute, Carmen Martín Gaite, Josefina Rodríguez, Concha Alós y María Victoria Atenzia. Aunque nos faltan conocimientos sobre la cuestión, me atrevería a señalar que, salvo en el caso de Martín Gaite, el medio cinematográfico no tendrá un papel tan decisivo en la formación estética -otra cosa es la formación sentimental- y en la labor creativa de estas autoras como sí lo tuvo, según hemos visto, en Rosa Chacel. Dejando a un lado la particular trayectoria biográfica de cada una de estas mujeres (De la Fuente, 2002), debe tenerse en cuenta que, en la Europa de los años 30 y 40, a la vez que va aumentando la con- ciencia de la repercusión social del cine y de su impacto en la transformación de las mentalidades, se produce un cambio en la actitud de los escritores e intelectuales, que se distancian del nuevo medio por razones a las que no es ajena la orientación dramático-realista que introdujo el cine sonoro y la narración clásica de Hollywood ${ }^{41}$, o que lo asumen como experiencia vital, de entretenimiento más o menos cotidiano, pero ya lejos de la reveladora experiencia estética que vivieron los artistas de la vanguardia. Habrá que esperar, terminada la Segunda Guerra Mundial, al contacto con nuevas tendencias literarias -en especial, la novela de la lost generation norteamericana-, a la difusión de los filmes del neorrealismo italiano y al desarrollo crítico de la teoría o política de los autores para que la literatura vuelva a acercarse al cine desde el reconocimiento de su especificidad artística. La propia Carmen Martín Gaite, que más de una vez se ha referido a la influencia del cine italiano en los escritores del medio siglo $(1994 / 2006,76-81)$ y que ya conocía a Sánchez Ferlosio y a Fernández Santos cuando se matriculan en el Instituto de Investigaciones y Experiencias Cinematográficas (I.I.E.C.), insistirá también, sin embargo, en la relación natural, nada académica ni culturalista, que tuvo este grupo con el medio fílmico, cuyo lenguaje habrian asimilado casi sin darse cuenta. "Los jóvenes picados por el aguijón de las letras no entendiamos de cine, pero íbamos mucho al cine, muchísimo", y aquel mundo en blanco y negro:

además de encandilarnos y aislarnos del otro en colores de la calle, nos proponía insensiblemente ese extraño pacto con la pantalla, donde abarcar más de lo que se ve forma parte de un código de sobrentendidos al que íbamos prestando adhesión sin darnos cuenta y que condicionaba nuestra forma de percibir después lo consabido. Aquella mirada oblicua y fragmentada de la cámara no suplantaba a la nuestra pero la iba complementando. Lo más significativo para mi -ahora que caigo en la cuenta- es que aquel trasvase o confluencia de aguas tenía lugar en un terreno no maleado por el prejuicio. Es decir, ni nos defendíamos de las posibles consecuencias de aquel influjo ni nos disponíamos conscientemente a aprovecharlo. Todos nuestros poros estaban abiertos a él, lo que pasa es que no nos enterábamos. $Y$ desde nuestra incipiente y más o menos ambiciosa vocación de novelistas, aprendiamos cine, se infiltraba el cine en nuestro quehacer. Se trataba de un aprendizaje deleitoso e insensible, como el de los primeros amores $(1995,54)$.

ARBOR Vol. 187748 marzo-abril [2011] 345-370 ISSN: 0210-1963

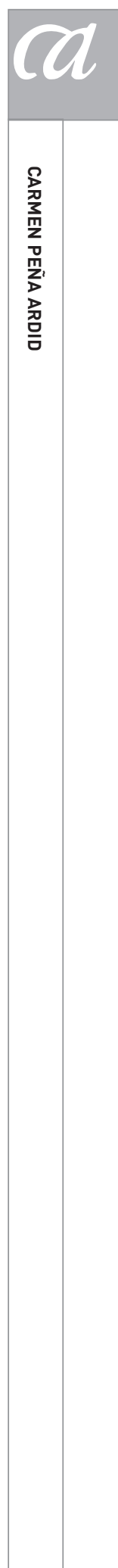


Algo diferente -y de la que sabemos bastante menos- fue la situación de las escritoras mayores que pudieron ver de niñas cine mudo y asistir después a los primeros pases de Raza (Saénz de Heredia, 1941) ${ }^{42}$, Cristina Guzmán (Gonzalo Delgrás, 1943), Ella, él y sus millones (Juan de Orduña, 1944) o El clavo (1944). Lo cierto es que no hay lugar para la "frivolidad" cinematográfica en Nada (1944), aunque mucho tenga que ver la novela de Carmen Laforet con la narrativa gótica de las escritoras anglosajonas, que el cine norteamericano -pienso en Jane Eyre o Rebeca- no deja de adaptar en esos años. Y apenas se encuentra tampoco referencia alguna en La plaça del diamant (1962) ${ }^{43}$, salvo cuando, al final de la novela, la hija de Natalia, Rita, decide casarse con el dueño de un bar-restaurante que la pretende con mucha insistencia porque "con la fama que le ponía, si no se casaba con él tendría que quedarse para vestir santos, y que eso tampoco le gustaba, porque ella quería, ya que no podía hacer lo que se había propuesto de servir en un avión, poder entrar en un cine o en un teatro con un hombre de buen ver a su lado y, el Vicenç, eso lo reconocía, era de buen ver" (Rodoreda, 237). Pequeña, pero interesante, es la aparición del cine en Nosotros, los Rivero (1952), novela de Dolores Medio que narra la historia de una familia ovetense entre 1924 y 1935 combinando el retrato de las costumbres provincianas y el enfoque social con un fondo de recuerdos autobiográficos. La penetración del universo fílmico en la vida de los personajes sale a la luz al describir el corrillo de viejas que en los soportales de una plaza "alcahueteaban, en los días de lluvia, los amores de las parejas que no podian ir al cine" (183), o las fotografias que llenan las paredes de la habitación de Ger, donde conviven Carlos Marx, Tagore, Gloria Swanson ${ }^{44}$ y "La Charito", bailarina del Café Suizo (111) ${ }^{45}$. Lena, la protagonista, es una de las "chicas raras" que pueblan la narrativa de las escritoras de postguerra, solitaria y resistente a la educación que se le impone, a los convencionalismos que limitan su esfera vital al ámbito doméstico y al matrimonio. Todavía niña reparte su admiración entre dos figuras míticas en su lejanía: el Príncipe de Asturias y Rodolfo Valentino ${ }^{46}$ :

Hasta el verano anterior, Lena conocia al Príncipe y a los Infantes sólo a través de las fotografías que Blanco y Negro y La Esfera publicaban de sus Altezas Reales. Y eso eran para la niña: fotografías. Y les admiraba como admiraba a Rodolfo Valentino, el galán de moda de la pantalla. Por aquella época recorría Lena las carteleras del Teatro Campoamor, del Jove- llanos, del Toreno arrancándoles (valiéndose de una gillette) las fotografías del ídolo para su álbum de artistas. También coleccionaba, en otro álbum, fotografías de la familia Real y de reyes y príncipes extranjeros. Todo sin el calor de una verdadera coleccionista, sino porque lo hacian sus compañeras de colegio. En realidad le resultaban más divertidas y más interesantes sus correrias por el patio de la Universidad, capitaneando a los muchachos del barrio (88).

Aunque Lena robe carteleras, como hará Antoine Doinel en Los cuatrocientos golpes (F. Truffaut, 1959), su afán coleccionista -y fetichista- carece de convicción. Imita la conducta romántica de sus compañeras pero parece decirnos que soñar vicariamente con Rodolfo Valentino no vale lo que sus correrías "capitaneando a los muchachos del barrio", del mismo modo que su interés por el Príncipe sólo cristaliza cuando hable brevemente con él. Hay aquí una mezcla de atracción y despego hacia el imaginario cinematográfico -sobre todo en las niñas y adolescentesque tendrá que ver con su difícil conquista de parcelas de libertad en la vida "real", aventura tanto o más apasionante y transgresora para los desarraigados personajes femeninos que las de la pantalla. De hecho, algo similar le ocurre a la protagonista de Los niños buenos (1957), cuento en el que Ana María Matute puso en evidencia graves fallas de la moral adulta: "A los siete años yo senté plaza de mala", afirma la narradora. "El caso es que nací cuando ya había en la casa tres varones bastante crecidos, y mi primer error fue pretender imitarlos, seguirlos a todas partes y admirarlos hasta el fanatismo". De nada sirve rezar por las noches para convertirse en uno de ellos. Cuando la expulsan del colegio, va a vivir con su abuelo a un pueblo de la montaña y será testigo de la llegada de un cinematógrafo ambulante, en una escena que parece extraída de un filme neorrealista:

Hasta que un día llegaron unos hombres a la aldea, conduciendo un anacrónico y destartalado camión. Pararon en la carretera, a la hora en que salíamos los muchachos de la escuela. Eran dos tipos jóvenes y rechonchos que merecian haber nacido hermanos. Llevaban monos azules y el cabello reluciente de petróleo.

-¡Atención, gentes de buena voluntad! -chillaron, en medio de la plaza.

$Y$ tras una larga charlatanería sacaron de unas cajas, con mucha precaución, dos máquinas maravillosas: una, para hacer cine, y la otra, para hacer tallarines (1957/1970, 139). 
Aunque pueda sorprendernos, a esta niña le atrae más la máquina de los tallarines -ha aprendido a usarla y acaba apoderándose de ella- que la peculiarisima y casi clandestina sesión de cine celebrada en una cuadra sofocante donde los jóvenes de la aldea, según la inocente descripción infantil, emiten suspiros y jadeos en medio de la oscuridad. No voy a extenderme en las concomitancias de la narrativa testimonial que cultiva Ana María Matute en los años 50-60 con los presupuestos del neorrealismo italiano -sobre todo en la línea humanista de Zavattini y De Sica-, pues han recibido ya la atención de Luis Miguel Fernández en un análisis minucioso de temas, cronotopos e ideario ético de la autora, centrado en los desheredados -la infancia o los viejos, como el solitario profesor de Vida nueva, tan semejante al de Umberto D (V. de Sica, 1952)- y en desvelar graves problemas de la España de postguerra: la miseria, el chabolismo, el paro (Fernández, 1992, 119171). La narrativa social de este periodo adoptaría a veces una óptica documentalista o incorporaría recursos que empiezan a relacionarse con el montaje cinematográfico para abordar el complejo tejido de las aglomeraciones urbanas y a los seres anónimos de ciudad, como ocurre en La noria (Luis Romero, 1951) o en el relato mucho menos conocido de Elena Quiroga, Trayecto Uno (1953). La historia aquí narrada, de acción escasa y protagonismo colectivo, transcurre en un espacio cerrado, el interior del autobús que hace el recorrido de Moncloa a la calle General Zabala, en Madrid, mientras suben y bajan gentes de variada condición, cuyos fragmentos de vida conoceremos a través del diálogo y de monólogos interiores filtrados por un narrador/a neutral que aspira a dar cuenta de sus inquietudes e ilusiones, pero también de los prejuicios y recelos con que se miran unos a otros. Aparte de la utilización de la técnica unanimista, heredera de Manhattan Transfer (John Dos Passos, 1925) o La noria, y presente en filmes como el célebre Rien que les heures (Cavalcanti, 1925), hay en el relato varias referencias al mundo del cine, casi indispensables en el paisaje de la gran urbe: alguien contempla "la escenografía" de la Plaza de España en la penumbra del atardecer; un pasajero sudamericano lleva un elegante abrigo que le da la apariencia de Stewart Granger, al decir de Lupita, su novia, quien "se volvía loca porque la llevase a los cines de la Gran Vía" (121-123), los mismos de los que "huyen" los matrimonios menos pudientes (125); mientras, alguien tomará conciencia de su visión discontinua de la calle, una visión móvil, fragmentada por el marco de la ventanilla que apenas permite captar fugazmente estímulos luminosos y algún título de la actualidad cinematográfica en las salas del centro de Madrid: "Anuncios. Letras. Figuras enormes. Fluorescencia. Verde, luz, rojo. "Cirano de Bergerac". Enormes figuras de cartón... "Actualidades". Cafés. "La Prensa". "Revuelta en Haití..." (124).

Entre visillos (1958), novela neorrealista algo tardía de Carmen Martín Gaite, ofrece seguramente una de las representaciones más ricas de lo que llegó a significar el cine para los jóvenes de la pequeña burguesía a mediados del pasado siglo, sobre todo en una ciudad de provincias. Era un ritual y una de las más importantes experiencias culturales a las que podían acceder, junto con los libros. Esta experiencia se vinculará además en la novela tanto al presente histórico del país -veladas alusiones a la censura, los ministros en el Nodo, la vigilancia moral de la iglesia, aunque también los cambios que anuncia la creación del I.I.E.C.- como a la existencia cotidiana de unos personajes vencidos en muchos casos por la resignación, el desamor y el miedo. El grupo principal lo constituyen, como es sabido, las jóvenes que viven "entre visillos", adoctrinadas en el ideario de la Sección Femenina y aceptando la tríada cortejo romántico-matrimonio-maternidad como única aventura de sus vidas; atrapadas, de hecho, en una forma de sentimentalidad que las condena a esperar a que el novio se coloque, al sufrimiento masoquista, la admiración del hacer ajeno y la negación de su propio deseo. En este contexto es donde la posibilidad o dificultad de ir al cine expresa también los condicionantes que limitan sus vidas. Puede ser la depresión de Isabel al reñir con el novio ("Acuérdate, la primavera pasada, que ni gana de ir al cine tenía", 19) o la soledad de Julia porque el suyo, que "hace cosas de cine", estudia en una escuela de la capital. También, el pesado código de los deberes del luto ("Elvira se levantó a echar las persianas y se acordó de que estaría por los menos año y medio sin ir al cine... Eran plazos consabidos... Con las medias grises la primera película. A eso se llamaba alivio de luto", 114), la manipulación de las conciencias en la confesión ("no vuelvas mucho al cine, hija. Hace siempre algún mal", 84) o los efectos del nacional-catolicismo en la clasificación moral de películas que tanto condicionó al cine español ("Voy esta tarde pero es dos erre. Marcelino pan y vino, una de un milagro, 84). En la novela no faltan las comparaciones de personajes con actores -James Mason, James Stewart-, aunque más singular es el recordatorio de que, en España, las películas 
no se ofrecían en versión original, por lo que, cualquier imitación verbal sólo lo sería de una voz intermediaria. Como cuando Goyita espía en el espejo la expresión de su rostro ("Luego dijo en voz lenta, parecida a la de los doblajes de las películas: "Te he echado tanto de menos, tanto...", 47) ${ }^{47}$. Otro aspecto no menos interesante, que anticipa visiones posteriores de lo fílmico en la literatura, es la indisoluble relación -cuando no existían los múltiples soportes actuales para conservar filmes- entre el pasado de la historia del cine y el pasado del propio sujeto que la evoca ("A Pablo le gustaba el cine Moderno, que se conservaba exactamente igual que él lo recordaba, con butacas de madera y novios baratos comiendo cacahuetes. Le dijo a Emilio que allí había visto él con su padre películas de Heintz Ruthman y de Janet Gaynor", 200) (Paech, 2002, 230) ${ }^{48}$. Pero Entre visillos describe especialmente bien el ritual de ir al cine, la reunión de amigas ante la taquilla, la entrada en la sala y el tiempo de tránsito, para quien llega tarde, hasta que la mente se centra en la proyección de la pantalla. ¿Es posible dejar siempre fuera del cine la historia personal?:

Julia no se enteró mucho de la película. Era de abordajes y hombres arrojados, una historia confusa. Les veía izar las velas del navio, y les admiraba perpleja y lejanamente. No era capaz de localizar aquellos mares y aquellas islas, ni se lo proponía, pero a ratos le parecía conocer tales paisajes, y unas rocas en tecnicolor eran de pronto las rocas de la playa de Santander donde Miguel y ella habian tomado el sol de hacía tres veranos, tumbados uno junto a otro. $Y$ se sentía inocente de recrearse en aquel placer ya purgado, como si fueran imágenes de la película que se desarrollaban ante sus ojos. Se encendieron las luces y hubo que tomar una actitud, levantarse, salir a la calle. Goyita se le cogió del brazo (118).

A diferencia de lo que sucederá en la narrativa de los años 70, donde lo real adquiere una dimensión prestigiosa por el hecho de parecerse a las imágenes (Peña Ardid, 2002b, 462-3), aquí, el paisaje "en tecnicolor" de los mares lejanos sólo atrae la mirada porque evoca lo real, una playa conocida, un trozo de vida de la espectadora, quien, por otra parte, no halla "lugar" en la fantasía de piratas del filme ${ }^{49}$. Carmen Martín Gaite había descrito en el cuento La oficina (1954) el desgarro que siente otra mujer cuando al finalizar la proyección se encienden luces de la sala y debe "salir del cine" (Peña Ardid, 1999). Pero esa entrega a la pantalla no es el tratamiento más habitual del tema en las narradoras de este período. Cuando Josefina Rodriguez Aldecoa, en su relato Los viejos domingos (1961)50, narra el primer amor de Sara -su anhelante espera de las tardes del domingo para coincidir con Diego en el cine del colegio religioso los Antonianos-, describe con todo detalle la algarabía y el ruido que precede a la entrada en la sala, la prescripción de no sentarse al lado de los chicos y la importancia de hacerlo en una fila cercana. Una vez que comienza la película, resulta que tampoco Sara llega a implicarse en la ficción ("un paraíso de caballos y tiros", para su amiga Cuca), sino que espia en las sombras, con un dolor que luego le parecerá ridículo, la butaca que ocupa otra chica junto a Diego. Esta distancia entre la desazón vital de las espectadoras y el universo de las películas se acentúa más aún en "Tarde en el cine" (1958), un cuento sobrecogedor de Mercè Rodoreda que nos hace asomarnos a un fragmento del diario de una joven que con ingenua sinceridad anota insignificantes pequeñeces de su vida y de un noviazgo que más que promesa de largos afectos parece una trampa:

DOMINGO, 2 DE JUNIO. Esta tarde he ido al Rialto con Ramón. Al entrar ya estábamos enfadados y mientras él compraba las entradas tenía ganas de llorar. Y todo por una tontería, lo sé.

[...] Por culpa del mercado negro no hemos visto el principio de la película y al ir a sentarnos todo el mundo protestaba... Los de la película sí que se querían. Me doy cuenta de que no nos queremos como ellos. Eran una espía y un soldado y al final fusilaban a los dos. En las películas siempre es muy bonito porque si los que se quieren son desdichados, sufres poco porque crees que todo irá bien; pero cuando la desdichada soy yo nunca tengo la seguridad de que todo vaya bien. $Y$ si alguna vez acaba mal, como hoy, todo el cine está triste y piensa: ¡qué lástima! Los días en que me siento muy desesperada, como nadie lo sabe, es peor. $Y$ si lo supieran, se reirian.

[...] Si alguien leyera esto se troncharía de risa. Ya sé que soy bobalicona, y mi padre siempre me dice que él [Ramón] es un simple, y es eso, en realidad, lo que más me entristece porque pienso que seremos un par de desgraciados. Pero, en fin... (Rodoreda, 2008, 75-78) $)^{51}$.

La posición sumisa y dependiente que se espera de las mujeres en las primeras décadas del franquismo propicia este lenguaje infantil, autocompasivo, desautorizado. Pero 
que impugna la idealizada imagen del amor de los discursos culturales como el cine -y la novela rosa, diría Martín Gaite-, tan desacordes con la experiencia de la vida a pesar de que en ambos -el cine y la vida- se "instituya" el matrimonio como el mejor "final feliz" para las películas y para las mujeres. Tal desenlace es el que viene a cuestionar otro breve relato de Josefina R. Aldecoa, Happy End, publicado ya en 1996, en el volumen Cuentos de cine que recopiló José Luis Borau con motivo del centenario del séptimo arte. La referencia inicial a Breve encuentro (véase nota 11), filme que, como se recordará, no concluye con la unión de los amantes, alude también a la reunión de dos viejas amigas, Julia y Cecilia, que tras años sin verse emprenden un corto viaje y acaban haciendo balance de los aciertos y errores de sus vidas. Los modelos cinematográficos a los que se adhieren figuran aquí como cristalización de aspiraciones, además de ser una forma indirecta de rendir cuentas con lo que han logrado o buscado ellas mismas y otras mujeres de su generación:

-De verdad, yo creo que el cine fue la clave de nuestra educación sentimental -dijo Julia-. El cine nos dio el modelo de persona que queríamos ser, el proyecto de vida que queríamos llevar. De algún modo, el cine nos hizo como somos (Aldecoa, 1996, 43).

Si esta impronta modelizadora es inseparable de la evocación de los tiempos más duros de la autarquía ("sin el cine no hubiéramos sabido lo que queríamos y no teníamos, lo que necesitábamos y no conocíamos"), al hacer explícita su juvenil identificación con géneros, actores y actrices, vuelven a dibujarse, un poco como en Barrio de Maravillas, dos opciones vitales para las mujeres -el modelo tradicional de la domesticidad y el modelo de la mujer independiente-, expresiones un tanto esquemáticas, si bien es eso lo que el relato busca, la ejemplaridad. La primera opción se plasma en el gusto de Cecilia por el western del cine clásico, un género patriarcal por excelencia, aunque no libre de contradicciones, en el que las mujeres desempeñan papeles muy pasivos al representar habitualmente la esfera de la familia y el cierre narrativo que permite la integración social del héroe mediante el matrimonio (Mulvey, 1981, 126-127):

Yo siempre pensaba en el Oeste, en los colonizadores. Me veía viviendo en una casa de madera con porche, en una pradera con un río abajo. Quería ser como ellas, con sus trajes recién planchados, el pelo graciosamente peinado, valientes, luchadoras, que lo mismo cocinaban que cuidaban el ganado y cultivaban la tierra. Habian Ilegado hasta alli con los restos de las vajillas arrastradas millas y millas en diligencias. Home, sweet home. Mi héroe era John Wayne, fuerte, animoso, de una pieza (44).

Julia, que ha buscado "ser algo por sí misma" y al hombre compañero más que al protector, dirigía su admiración a "aquellas mujeres en blanco y negro que se lanzaban a las calles de Nueva York", abogadas con oficinas de cristal en los rascacielos:

Otra vez la elección ¿campo salvaje o gran ciudad? Yo elegí la gran ciudad. Yo descubri la gran ciudad en el cine. Deseé huir de mi vida provinciana en el cine. Katherine Hepburn era mi modelo. Aquel pelo, aquellos trajes, aquel carácter rebelde, abierto, triunfador. Recuerdo expresiones, gestos de la Katherine de aquellos años y no recuerdo la cara de mi madre entonces. Ni cómo era ni cómo vestía. ¿Era más real para mi Katherine? ¿Era mi madre tan fantasmal?

Entre las escasas actrices que han podido construir personajes protagonistas profundos, lejos de estereotipos, Katherine Hepburn, junto con Bette Davis y Joan Crawford, representó para muchas mujeres de los años 40-50 "images of power and confidence" (Stacey, 1994, 154-5). Encarna aquí además una imagen femenina positiva, rebelde y resistente al modelo patriarcal, un punto de referencia válido para las "hijas", como no lo fueron las propias madres biológicas, figuras ausentes o "fantasmales" para muchas escritoras españolas de estos años, de lo que queda amplio testimonio en la obra de Ana María Matute, Ana María Moix, Esther Tusquets o Almudena Grandes (Redondo Goicoechea, 2003, 22-23). Voviendo a Happy End, tanto Cecilia como Julia recorrieron el camino proyectado, aunque no sin heridas. Cecilia consiguió el albergue soñado y a los niños, pero arrastra la decepción que sufrió más de una esposa burguesa en la prosperidad de los años 80 ("Pero John Wayne me ha fallado. John Wayne era un bluff..., por pura casualidad, me entero de que el tal Wayne tiene un asunto estable y duradero, desde hace dos años. ¿Sabes con quién? Con la hija de una amiga mía", 46). Mejor balance admite el trayecto de Julia, si bien no sólo por haber logrado una mayor autosuficiencia, sino un alto grado de lucidez: "aquellas películas de entonces, las del final feliz tenian una trampa. Terminaban justo donde

ARBOR Vol. 187748 marzo-abril [2011] 345-370 ISSN: 0210-1963

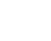


empieza todo"; más aún, el verdadero final feliz, es la satisfacción, sin duda pasajera, del breve encuentro con su amiga. ¿Y qué queda del cine? La experiencia de Julia, espectadora que acude en Nueva York a una sala donde estrenan Manhattan (Woody Allen, 1979) y siente que la imagen puede ser tanto o más verdadera que lo real, que el imaginario cinematográfico es una mediación irrenunciable de nuestro saber sobre el mundo:

Me senté en una butaca y cuando empezó la película y apareció en pantalla el telón de rascacielos en blanco y negro y sonó la música de George Gershwin, no pude soportarlo y me eché a llorar. Descubrí que aquél, el de la pantalla, era mi verdadero Nueva York. El cine nos da lo que deseamos alcanzar. Que no es más real en el cine pero sí más verdadero. Yo estaba en el Nueva York real pero el cine me daba la nostalgia de Nueva York (47).

La progresiva disolución de la estética realista a lo largo de los años 60 orientó la práctica literaria, como es bien sabido, hacia formas expresivas más experimentales, el dominio de la subjetividad, el gusto por la memoria personal y la apertura de la novela y la poesía a un universo de referencias culturales en el que los mass media, y especialmente el cine -aunque también la fotografía y la televisión-, adquieren una importancia que aún no ha decrecido. En esta renovación participaron algunas de las autoras de la "generación de los 50" y, por supuesto, las voces más jóvenes que van apareciendo en la década siguiente y permiten hablar de un auténtico florecimiento de la literatura escrita por las mujeres (Ruiz Guerrero, 1997, 167-176): Esther Tusquets, Enriqueta Antolín, Lourdes Ortiz, Ana María Moix, Montserrat Roig, Soledad Puértolas, Nuria Amat, Ángeles Mora, Ana María Navales, entre otras. Respecto a la presencia del fenómeno cinematográfico, no cabe establecer divisiones tajantes entre grupos generacionales, ya que, por ejemplo, será en la poesía que, tras un largo silencio, escribe María Victoria Atencia en los años 70 (Marta \& María, 1976) cuando el cine asoma como estímulo creativo de sus breves poemas. Y más significativo es el caso de Carmen Martín Gaite, en cuya novelística se intensifica el vínculo intertextual con el medio cinematográfico -sobre todo, desde El cuarto de atrás (1978)-, sea como recurso metafictivo que pone en entredicho el realismo del universo representado en la novela mediante alusiones al dispositivo cinematográfico que va a compararse con el modo de discurrir inconexo de la memoria (y de la narración); sea como motivo temático, con numerosas citas en Nubosidad variable (1992), Lo raro es vivir (1996) o, de nuevo, El cuarto de atrás, donde las alusiones a fragmentos de filmes, personajes o paratextos fílmicos no sólo remiten a vivencias del pasado de la protagonista-narradora, sino que adquieren un significado que trasciende lo individual y se proyecta en la Historia, en la medida en que el cine aparece -y esto es característico de toda la obra de Martín Gaite- como uno de los ingredientes esenciales de la cultura popular que define la intrahistoria de la España franquista.

En cuanto a las escritoras más jóvenes que van a darse a conocer a partir de los años 70, es característica común a su literatura el autoanálisis y la revisión de los valores de la tradición, con un enfrentamiento más radical que el de sus predecesoras a las expectativas sociales sobre la femineidad. De hecho, la influencia de los postulados feministas, en su amplitud y diversidad teórica, es un rasgo compartido por autoras tan diferentes como Ana María Moix, Montserrat Roig, Rosa Montero, Esther Tusquets, Nuria Amat, Marian Izaguirre, Almudena Grandes, Ángela Vallvey, entre otras. Y ello afecta inevitablemente a su posición como espectadoras de cine; unas espectadoras a las que el interés por el medio no impide señalar las exclusiones inherentes a los modelos hegemónicos de representación y al glamour de estereotipos que no sólo siguen representando a las mujeres en los papeles tradicionales, marcados por la pasividad y la impotencia, de víctimas, seductoras y objetos sexuales, sino que también invisibilizan cualquier tratamiento serio de la homosexualidad femenina. Así, junto a poemas que rinden homenaje al cine o un filme [como "Casablanca" (1985), de Ángeles Mora, o Conversaciones con Mary Shelley (2006), de Julia Piera], en torno a El espíritu de la colmena, no faltarán textos tan amargos como "Mujer ciega" (2001), de Miriam Reyes, ni el tratamiento profundamente irónico de los iconos-estrellas femeninas y masculinas por parte de Almudena Grandes o la desmitificación característica de las novelas de Ángela Vallvey, sin olvidar libros de tanta lucidez como Máquinas de amar. Secretos del cuerpo artificial, donde la escritora Pilar Pedraza analiza las formas que en la literatura, la plástica y la cinematografía, ha dado la imaginación masculina al mito de Pigmalión, a la fantasía de producir criaturas femeninas más hermosas y mejores que las mujeres. El estudio del lugar que ocupa el cine en la obra de las autoras españolas de las últimas 
décadas queda, sin embargo, fuera de los límites de este artículo. Y merece una atención especial seguir el curso de esas voces, desde la Transición política hasta la actua- lidad, teniendo en cuenta que el territorio de la crítica no académica del cine sigue siendo raramente frecuentado por las mujeres.

\section{NOTAS}

1 Hay bastantes trabajos sectoriales acerca de la recepción inicial del cinematógrafo en España $y$, en menor medida, sobre otros periodos, pero, aunque se interesan por los públicos, no adoptan perspectivas de género que contemplen, más allá de los reclamos publicitarios, las condiciones de acceso de hombres y mujeres a las salas, los tipos de programación, posibilidades de compra de revistas, censura, etc. Véase Sánchez Vidal (1996), Gonzalvo Vallespi (1996), Jurado Arroyo (1997) o López Serrano (1999).

2 El interés por conjugar el concepto "abstracto y ahistórico" de la espectadora, según los postulados de la semiótica y el psicoanálisis, con una visión contextualizada históricamente (que no renuncia a los métodos de las ciencias sociales) ha sido una tendencia creciente de la teoría feminista del cine, sobre todo en el ámbito anglosajón. Un estado de la cuestión puede consultarse en Janet McCabe (2004, 37-64).

3 En un relato de Esther Tusquets, En la ciudad sin mar (Siete miradas en un mismo paisaje) (1981), Sara vive gozosamente, a fines de los 50 , su excepcional libertad cuando inicia sus estudios universitarios en una ciudad donde no conoce a nadie: "no había existido apenas en su vida de niña acomodada espacio y margen para la soledad, soledad que habia tenido que irse ganando trabajosamente paso a paso"; "se había embriagado a grandes sorbos de independencia y soledad y no se cansaba de andar sin compañia y a la deriva por las calles, de meterse sola en un cine $o$ en el teatro, de sentarse sin más en un banco público" (83); "vagando abstraida por las salas...del Museo, yendo, deliberadamente sin compañia, al teatro, al cine, a algún concierto, lo cual no habia tenido ocasión de hacer hasta entonces jamás" (86).

4 Conocidas son las sesiones para el público infantil, habituales desde 1907, a las que "acuden señoras distinguidas y niños preciosos" (López Serrano, 1999, 233). Que la afición podía estar reñida con la dependencia lo muestra la noticia - ¿falsa?que apareció en la prensa en 1935 sobre "la joven madrileña que se tiró por una ventana porque su novio no quería llevarla al cine" (Sánchez Vidal, 1996, I, 215).

5 El diálogo sainetesco rebaja el tono amargo de la escena entre Teresa, la hija de don Quintín, y la soñadora Felisa: "-Pues no estás viendo lo que es mi vida. Hambre, golpes, miseria" I -"Puede que tengas razón. Y sobre todo, que la que más y la que menos tiene sus ilusiones. $Y$ en esta soledad iquién va a reparar en los atrativos (sic) incógnitos de una!" / -"Verdaderamente que en una carretera, por mucho que sueñes, lo único que vas a conseguir es que tu padre te quite los atractivos de un garrotazo el día que te vea en una de esas posturas". I - "No lo puedo remediar. Cada vez que veo una de estas fotos me entra un hormiguillo y un afán de que estoy
Aceptado: 25 de marzo de 2009 
perdiendo la ocasión de ser la Greta Garbo española". / - "Como que si el chico del señor Pérez te sigue trayendo revistas de cine, te van a tener que llevar a Ciempozuelos". I -"Tú que sabes, so prosáica. Ya verás el día en que yo sea elegida Miss España y me den un contrato la que voy a armar". I - "Que la Marlén (sic) va a tener que pedir un estanco, no te digo más".

6 Ilusión que motiva jocosos diálogos y canciones a dúo con su pretendiente, que interpela a Solilla con piropos: "-¿Es a mí? / - "¡A tí! ¡So Marlén Dietriche!" (sic). Sobre la génesis y construcción del estrellato de Marlene Dietrich son fundamentales los trabajos de Hilaria Loyo (2002; 2005).

7 Labanyi anuncia, en este trabajo, el inicio de un proyecto de investigación titulado "Una historia oral del público cinematográfico en la España de los años cuarenta y cincuenta" $(2002,43)$, cuyos resultados podrian, sin duda, despejar algunas incógnitas que aquí presentamos.

8 Al estudiar estas adaptaciones, Carmen Andreu nota la importancia que las revistas de cine daban a la descripción minuciosa del costoso vestuario -Primer Plano tenía una sección fija llamada Desfile de la Moda Cinematográfica. Estaba muy arraigada la idea de que "el placer espectatorial que producía la contemplación de los vestidos en escena era totalmente femenino" y "se era plenamente consciente del poder del cine como generador de conductas de imitación" (2007, 25-26).

9 Interesante es el capítulo "Gente honrada" de La noria (Luis Romero, 1952), donde Elvira, joven soltera que trabaja en un bufete, planea sorprender a su madre viuda invitándola a ver Locura de Amor, "que le han di- cho que es muy bonita y la proyectan en un cine que está aquí cerca; un cine baratito donde van algunos días" (97). Mientras viaja en tranvía, su pensamiento vuela de un posible futuro de casada a todo lo que le sugiere el filme de Juan de Orduña: "Este González...Sí, seguro que sí...es imposible que me equivoque. Chico serio...Jefe de negociado. Tímido; hoy parecia que...Un hombre íntegro [...] Elvira, doña Elvira; dos hijos. ¡Ay Dios! Mamá; Locura de amor, Juana la loca. El ataúd, día gris, viento. "Juana la loca -tiene una toca- Ilena de..." ¡Ay, Señor! No, no, es feo...Sala de los abuelos; cuadro de Padilla, miedo. González, ternura. Buen padre..." (91). Sobre Locura de amor, véase Donapetry (2006).

10 Entre las excepciones, véase Santos Fontela (1975, 111-138). Sobre la inquietud que generó la recepción de La tía Tula (Miguel Picazo, 1964) por parte de las espectadoras, véase $C$. Peña Ardid (2002a, 446-7).

11 Muy significativo es el comienzo del cuento de Josefina R. Aldecoa, Happy End: "-Qué lugar para un 'breve encuentro' -dijo Julia / -¿Con Harrison Ford o con Trevor Howard? -preguntó Cecilia. / -Con Trevor Howard, desde luego -aclaró Julia" (1996, 37). Como la autora, los personajes pertenecen a la generación de los 50 y se muestran fieles a la emoción que les produjo el filme británico Breve encuentro (Brief Encounter, David Lean, 1945) y a un modelo (europeo) de masculinidad refinada, sensible y altruista, que representaba el médico interpretado por Trevor Howard.

12 Sobre todo si pertenecen a la estirpe de "la chica rara", genealogía de personajes sobre la que llamó la atención, como se sabe, Carmen Martín Gaite (1993, 101-127), fundándola en Andrea, la protagonista de Nada (Carmen Laforet, 1945).

13 "¿Y cómo darles a Conchita y a Coralito y a sus amigas y a sus madres esta versión de Lo que el viento se llevó, cuando todas habian sorbido los vientos por Red Butler y por Ashley y habian Ilorado a lágrima viva la muerte de Melania y sentido una profunda envidia, teñida de reproche, contra Escarlata? ¿Y cómo confesarme a mí misma que, a pesar de reconocer sin apelación la certeza del criterio materno, seguían deleitándome las interminables aventuras de aquel folletín que fagocité más que leí, en cuanto se publicó, todas las noches del verano siguiente?" (Falcón, 2003, 38).

14 El análisis de temas o recursos fílmicos en la obra de Chacel, Ana M. ${ }^{2}$ Matute, Martín Gaite, Rosa Montero, Belén Gopegui ha sido abordado en estudios de conjunto (Morris, 1980; Fernández, 1992; Carmen Peña, 1999; 2001; Marí, 2003). Sobre Almudena Grandes, véase García-Abad (2006; 2007).

15 Sorprende, sin embargo, que incorporen muy pocas voces de escritoras.

16 A Luis Miguel Fernández (1997) debemos el haber dado a conocer varios textos de Pardo Bazán sobre cine, situándolos en contraste con la opinión de otros escritores de generaciones posteriores, como Pérez de Ayala o Unamuno, mucho más cautos en su apreciación del nuevo medio. En 2005, la revista Archivos dedicó, en su n. ${ }^{\circ} 51$, un monográfico a "El cine según Emilia Pardo Bazán", reproduciendo dos artículos de la autora, aunque no se recoge uno de los más importantes sobre Cabiria, que sí comenta Fernández.

17 "Confesaré que las películas limitadas a reproducir espectáculos y cua- 
dros de la naturaleza y la realidad me gustan muchísimo. La agitación magnífica del mar, las cascadas y sabanas de los grandes ríos del Nuevo Continente, la subida de la marea, el avance y paso de un tren..., donde se ve que la escena ha sido sorprendida y no preparada [...] Y he aquí como las teorias ortodoxas de estética pueden aplicarse hasta a los cinematógrafos -y salir confirmadas-" (La llustración Artística, 7 de diciembre de 1908).

18 "Del cinematográfo no se hacen encomios, pero ha llegado a la perfección, y entrado en los dominios del arte. Mejor que el teatro, nos da la plástica y la mímica, y en cuanto a la escenografía, pone en juego elementos de realidad, imposibles de llevar a las tablas" (La llustración Artística, 25 de enero de 1915).

$19 \mathrm{El}$ personaje del forzudo Maciste alcanzó tal popularidad que llegó a tener una serie propia. Estaba interpretado por un antiguo descargador del muelle de Génova, Bartolomeo Pagano, y no era negro, aunque actuaba embetunado (Sánchez Vidal, I, 1996, 126).

20 "Mi impresión de conjunto es ya francamente favorable al cinematógrafo, que ha llegado a contarse entre mis distracciones favoritas, sobre todo en invierno, en las largas tardes de invierno, en Madrid, cuando la gente se refugia de buena gana en locales cerrados, iba a decir abrigados, aun cuando la calefacción, muchas veces, sea un mito" (Archivos, 2005, 157).

21 Esta "fuerza" de los personajes podía ser polo de atracción para las espectadoras adolescentes (pensemos que no tardaría en aparecer Celia, de Elena Fortún). Sin duda, habría que matizar mejor la tipología de caracteres representados por las actrices mencionadas, aunque en el caso de
M. Clark, casi todas sus películas están perdidas. Mary Pickford interpretó 34 films entre 1913 y 1919 con importantes directores (Cecil B. de Mille, Allan Dwan o Maurice Tourneur) y sus famosos papeles de niña pequeña, en los que siempre salvaba a su familia (The Poor Little Rich Girl, Stella Maris), no eran inocentes, sino activos y traviesos. Pauline Frederick, heroína de la desventura que vestía con túnicas griegas, sí encarnó papeles más trágicos que intentaban competir con las grandes divas italianas. Sobre estas primeras estrellas, véase Tom Gunning (1994). Sobre el melodrama mudo, véase Silvia Rins (2001).

22 Recordemos que en el "Primer Manifiesto de la Cinematografía Futurista" (1916), el rechazo a los géneros dominantes también se plantea en los mismos términos: "excepto algunos filmes interesantes de viajes, cazas, guerras, etc. no han sabido infligirnos más que dramas, dramones y dramitas pasaditísimos".

23 En la última sesión del Cine-Club de La Gaceta Literaria (9 de mayo de 1931) se proyectó el viejo reportaje Antología del beso, lo que demostraba, según Morris, "the fascination exercised in Spain by a physical contact that, subject to only minimal restraints on the screen, was still controlled in real life by rigid standards of decorum" (Morris, 1980, 10). Mucho más reciente es el artículo, ampliamente ilustrado, "El nuevo arte del beso", incluido en el monográfico de Litoral. La poesía del cine (n. ${ }^{\circ} 235$, 2004) que se abre con una fotografía que sugiere una felación.

24 En el prefacio a Cine de mujeres, recuerda Annette Kuhn su gran impresión "al darme cuenta de que, en todos mis años de arrebatada asis- tencia al cine, el placer que había sentido se había debido en gran medida a mi identificación con personajes masculinos. Es decir, yo me había estado colocando en el papel del hombre, del héroe para disfrutar -quizá incluso para entender- las películas" $(1991,9)$. Sobre el tema, véase también Teresa de Lauretis (1992, 223-228).

25 Véase también en Historia de una maestra, de Josefina Aldecoa, la llegada de las Misiones Pedagógicas al pueblo leonés donde ejerce Gabriela y la expectación de los habitantes ante el cine (1990, 134-142).

26 Más de una decena de obras teatrales de Lejárraga/Martínez Sierra fueron adaptadas en Hollywood (entre ellas, Canción de cuna; Una viuda romántica; Yo, tú, ella; Julieta compra un hijo). $Y$ otras tantas en España y Argentina (Mamá, El amor brujo, Susana tiene un secreto). Tras la muerte de su marido en 1950, se trasladó a Hollywood para ofrecer -con su propio nombre- algunos cuentos infantiles a la Disney, aunque sin éxito. Pero en 1955 aparece La Dama y el vagabundo, presumiblemente basada en un relato de Lejárraga, Marlín y Viviana o el perro tonto y la gata egoista. Sin embargo, su autoría nunca fue reconocida (Brox Orive/ Cabezón, 1998, 82).

27 "El cinema en España" y "Encuesta a los escritores ¿Desde su punto de vista literario, qué opinión tiene usted del cinema?" (n. $\left.{ }^{\circ} 43,11-10-28\right)$; "Picadilly" (n. $\left.{ }^{\circ} 56,15-4-29\right)$.

28 No era España en esto una excepción. Durante muchas décadas, la obra de cineastas como Alice Guy, Lotte Reineger, Elvira Notari, Asta Nielsen, Germaine Dulac o Maya Deren fue posible porque trabajaron desde sus propias productoras y al margen de la 
gran industria. Una de las pocas que no cumple esta norma fue Dorothy Arzner, contratada desde los años 20 por la Paramount.

$29 \mathrm{El}$ original argumento comienza cuando un grupo de taxis parados en la madrugada comienzan a contar historias sucedidas durante sus trayectos. En la historia principal, Carmen, modista de una casa de modas, se viste de hombre, haciéndose llamar Jaime, para acercase a Fernando, del que se ha enamorado. Entabla amistad con él pero enamora también a su amante, Elena, y a una de sus amigas. Véase Utrera (2000, 71-5).

30 En uno de los relatos de la Colección Cuentos de la España actual, titulado "Liberación de octubre", título que alude, a la vez, al levantamiento de los mineros de Asturias el 5 de octubre de 1934 y a la liberación de una mujer, Rosa, que abandona al marido por la revolución, se describe la miseria material y moral que rodea a esta malcasada, sólo compensada por la alegría del cine, al que -de nuevo- no puede ir sola: "Rosa no quitó nunca la hoja del calendario. Quedó en el n. ${ }^{\circ}$, en el n. ${ }^{\circ} 4$ en negro, porque no era domingo y sólo los domingos se enrojecía la cifra para recordarla: hoy vas al cine. Así descubría entre los trajines y afanes de la casa que era una mujer. Sí, una mujer, aunque su marido la apartase de su camino y sólo volviese a sosegarla una vez semanalmente: "Mañana, al cine". ¡Con qué pulcritud doblaba en cuatro dobleces, su agradecimiento y se lo entregaba, rendida, al darle la servilleta limpia los domingos y empezar a comer." (M. Teresa León, 1934/2003, 192).

31 Verardini participó en Una encuenta sobre el cine sonoro (La Gaceta
Literaria, n. 69 , 1-11-1929). En los años 30 escribe además en la revista Estampa (Madrid), publicación en la que apareció también el artículo-entrevista de Carabias: "Catalina Bárcena habla de Greta Garbo, Marlene Dietrich, Joan Crawford, Chevalier, Dolores del Río" (n. $\left.{ }^{\circ} 316,1934\right)$.

32 La estética del fragmentarismo y las transiciones rápidas ("!ué limitación la del teatro! No poder seguir la acción fugitiva, tener que constituirse los actos con pies y cabeza [...] ¡Imposible! Jamás prescindiré de esas situaciones transitorias en que la acción va a toda marcha [...] Esto sólo en el cine: tendré que prescindir del concierto musical y compaginar la armonía plástica"). Posibilidad de invertir la marcha de la acción ("En el cine conseguiría inmediatamente el reverso de la escena"). La movilidad del encuadre y variación del tamaño de los objetos ("Mi protagonista se perderá entre las formas que invadirán la pantalla, desbordando de ella, estallando por su propio tamaño en la oscuridad"). Homenajes al universo surreal de los cómicos del mudo ("Mi drama sería cinematizable a lo Harold Lloyd. Aunque yo no use su perenne risa dentrífica...") (Chacel, 1930/1974, 106-117).

33 El título del cuento se inspira en la publicidad de una loción cosmética que se anunciaba en los periódicos romanos, véase Costa Staksrud (2001, 198-199).

34 De semblante muy dulce, Gaynor fue una de las mayores estrellas del final de la época muda. Había interpretado también El séptimo cielo (Borzage, 1927) y Amanecer (Murnau, 1927).

35 Entre otros, se comentan en el primer volumen -Alcancía. Ida-, no siempre elogiosamente, Guerra y Paz (King Vidor, 1956); Sonrisas de una noche de verano (Bergman, 1955); Cowboy (Delmer Daves, 1958); Sombras de sospecha (M. Anderson, 1961); Julio César (Mankiewicz, 1953). 0 la retrospectiva del Museo de Arte Moderno de Río de Janeiro (Le mystère du Château du Dès, La coquille et le clergyman; Faits divers, Woman (La fille de la mer). En el segundo volumen, Alcancía. Vuelta, las referencias son aún más numerosas: Vivir en la cumbre (Ted Kotcheff, 1966), El perro rabioso (Kurosawa, 1949); Cuatro pasos por la nubes (Blasetti, 1942); La vieja dama indigna (René Allio, 1964); El baile de los vampiros (Polanski, 1967); Un hombre llamado caballo (Silverstein, 1970); La chinoise (Godard, 1967); El Premio (Mark Robson, 1963); La rosa (Mark Ridell, 1979). Algunos títulos son difíciles de identificar por falta de datos o porque sólo ofrece el título del estreno en Brasil.

36 "Me fui sola por la tarde a ver Los vikingos, una de esas películas que la gente culta está obligada a considerar malas" (Ida, 141); "Interrumpí esto porque estaba cansada; salí, ví en el Copacabana un 007, Dr. No, y me metí a verlo porque siempre es estimulante ver un cuerpo maravilloso de los buenos tiempos... Ayer ví por segunda vez Women in love ..." (Vuelta, 252).

37 "Ayer vi Belle de jour; qué extraño caso el de Buñuel, qué mezcla de talento y de trivialidad, aunque tal vez la mezcla no sea de esos dos elementos, sino más bien de habilidad y oportunismo" (Vuelta, 113).

38 "iMaravillosa visión de Londres! Color extraordinario y isilencio! Creo que Antonioni es el único capaz de fotografiar el silencio. Mejor dicho, filmarlo en su cinematicidad. Ausencia total de estulta música de fondo: los 
ruidos son los ruidos reales que corresponden a cada situación; las pisadas en la calle, el grifo del agua en el laboratorio, el rumor de los árboles en el parque [...] ya en El eclipse me pareció maravillosa aquella noche de verano en que se oye solamente en la calle la máquina de escribir"; "El film me hizo pensar, mientras transcurría, en lo que tanto he pensado: la modernidad, la posibilidad o imposibilidad de entrar en este tiempo, vivirlo como lo viven estos veinteañeros..." (Vuelta, 70 y 74).

39 "A veces me siento impresionada o atraída por cosas o sensaciones que, en el cine, es completamente imposible percibir... Yo encontraba muy atractivo a John Gilbert principalmente por su color... Bueno, en aquel tiempo, hablar de color en el cine era absurdo, pero yo veía el color de John Gilbert como su mayor encanto. He tenido otras muchas sensaciones raras... viendo una película de Mel Ferrer -no recuerdo cuál- noté, en el momento en que la actriz le besaba, el perfume del jabón de afeitar. Otra, muy importante, el perfume de Anna Magnani, en La voz humana. Olor a mujer poco bañada, a mujer pobre" (Ida, 139).

40 Aunque la escritora catalana (19091983) publicó algunas novelas ya en 1933 y vivió, tras la guerra civil, exiliada en Ginebra, su carrera literaria la retoma propiamente al final de los años 40 y se dará a conocer con publicaciones como Veintidós cuentos (1958) o La plaça del diamant (1962). Véase el número monográfico de Turia (n. ${ }^{\circ} 87$, junio-octubre 2008).

41 Naturalmente, no es el caso de los dramaturgos y dramaturgas. Lo eran Margarita Robles y Natividad Zaro, que trabajaron como guionistas en los años 40-50. Robles participó en muchas adaptaciones (Altar mayor, La condesa María, Cristina Guzmán). Natividad Zaro fue coautora del guión de Surcos (Nieves Conde, 1951) (Riambau y Torreiro, 1998).

42 En el relato memorialista Adolescencia en Barcelona hacia 1970, Laura Freixas escribe: "Pobres madres de la España de entonces: educadas, cuando fueron hijas, con el catecismo del padre Ripalda, el Viernes Santo sin cine ni playa, Raza y misa con mantilla, y teniendo que educar a las suyas en un mundo donde circulaban el bikini y la pilule, El último tango en Paris y Janis Joplin" $(2007,141)$

43 La adaptación cinematográfica de Francesc Betriú (1982) añadió, en cambio, una secuencia en la que Julieta y Natalia están viendo La aldea maldita (Florian Rey, 1931), concretamente, la escena en la que Acacia es simbólicamente apedreada por los niños de la escuela.

44 La gran actriz del cine mudo, inmortalizada también por Billy Wilder en El crepúsculo de los dioses (1950), fue modelo de famosos fotógrafos, entre ellos Edward Steichen que aumentó su misterio y glamour en el famoso retrato con un velo de encaje en 1924.

45 En 1965, Dolores Medio hizo un curso de guionista en Televisión Española y, a partir del año siguiente, varias novelas y cuentos suyos serán adaptados a la pequeña pantalla. Un gran éxito tuvo en 1969 la versión de Nosotros los Rivero, que ella misma adaptó en quince capítulos para el espacio Novela, bajo la dirección de Pedro Amalio López (López Alonso, 1993, 21-22).

46 Sobre el culto a Valentino, el tratamiento publicitario de su figura y su conversión en objeto erótico para las audiencias femeninas de los años 20, cf. M. Hansen (2000).
47 Véase el tema del doblaje también en su novela El cuarto de atrás (1978, 112).

48 La novela también introduce recursos cuyo origen remite a la percepción cinematográfica. Por ejemplo, angulaciones y segmentos del campo visual que el cine ha enseñado a valorar: "unas señoras... me pidieron que las dejara pasar... Eché escaleras arriba detrás de ellas acomodando mi paso al suyo porque no quería adelantarlas. Sus tacones se movían de un peldaño a otro y hacian variar la postura de sus cuerpos esforzadamente, como en los saltos de la cámara lenta" (52). 0 los trucos ópticos que deforman lo real y expresan visiones subjetivas: "Teo me preguntó cosas del viaje a Suiza..., y yo, mientras contestaba, no podía dejar de pensar en Elvira. La veía entre las otras personas agrupadas al extremo opuesto de la habitación, igual que si la mirase por unos prismáticos puestos del revés. El humo del pitillo me alargaba y alejaba la habitación, volvía casi irreales las cosas que estaba contando. Muy allá, en la pared de enfrente, habia un aparador con espejo biselado y el espejo reflejaba múltiples cabezas que se movían (59).

49 Lo mismo le ha ocurrido con la proyección del NODO: "Julia buscó las gafas dentro del bolso. Lo del embase era aburrido. Igual que otras veces: obreros trabajando y vagonetas, una máquina muy grande, los ministros en un puente. Luego cambiaba y salía el mar, unas regatas. Anda, si era Santander, ¿Sería verano? ¿Estaría Miguel por allí? Piquío. ¡Qué maraviIla si le viera! Buscaba con desazón el hueco más propicio entre las cabezas de los de delante" (116-117). En la narrativa neorrealista de los $50 \mathrm{y}$, 
sobre todo, en Martín Gaite es frecuente establecer un contraste entre la seriedad de la vida y la fascinante evasión cinematográfica. A veces, poniendo literalmente en paralelo ambos mundos, como en el cuento Un día de libertad (1953). Alternativa y simultáneamente, accedemos a los pensamientos del marido que no se atreve a contar a su mujer que ha perdido el trabajo, y al torpe relato que ella hace de la película del oeste que acaba de ver (Martín Gaite, El balneario, 1983, 136-140).

50 En 1954, Josefina Rodríguez escribió con su marido, Ignacio Aldecoa, la sinopsis argumental de un guión de cine titulado Cuatro esquinas (Fernández, 1992, 84).

51 En varios cuentos de Rodoreda se advierte también la huella de la temática y recursos del cine. Véase Un hombre solo (Veintidós cuentos) o, también, Vivir al día (Parecía de seda y otras narraciones, 1978), texto dramatizado en el que cuatro mujeres burguesas quedan a tomar el té en la tarde del 18 de julio de 1936. Aunque la acción concluye cuando marchan a sus casas, el relato añade un escueto informe -como al final de muchas películaspara dar cuenta de la suerte que corrieron cada uno de los personajes.

\section{BIBLIOGRAFÍA}

Aldecoa, Josefina R. (1961): "Los viejos domingos", en Alicia Redondo Goicoechea (ed.), Relatos de novelistas españolas. 1939-1969, Madrid, Castalia, 1993.

- $\quad$ (1990): Historia de una maestra, Barcelona, Anagrama, 1996.

- (1996): "Happy End", en José Luis Borau (ed.), Cuentos de cine, Madrid, Alfaguara.
Andreu Gisbert, Carmen (2006): Melodrama histórico-literario de los años 40: modelos femeninos en el cine español del primer franquismo. DEA presentado en septiembre de 2007, dentro del Programa de Doctorado Estudios de Mujeres, de la Facultad de Filosofía y Letras de la Universidad de Zaragoza. Inédito.

Atencia, María Victoria (1990), Antología poética. Edición de José Luis García Martín, Madrid, Castalia.

Borau, José Luis (ed.) (1996): Cuentos de cine. Grandes narradores celebran el primer siglo de cine, Madrid, Alfaguara.

Brox Orive, Luis/Cabezón, Luis Alberto (1998): "La Rioja", en AA.W., Cine español. Una historia por autonomías. Vol II., Barcelona, Promociones y Publicaciones Universitarias, pp. 75-115.

Chacel, Rosa (1928): Chinina Migone, Revista de Occidente. Tomo XIX (enerofebrero-marzo), pp. 79-89.

- (1930): Estación. Ida y Vuelta, Madrid, CVS Ediciones, 1974.

- (1971): La confesión, Barcelona, Edhasa.

- (1972): Saturnal, Barcelona, Seix Barral.

- (1976): Barrio de Maravillas. Edición, Introducción y notas de Ana Rodríguez-Fisher, Madrid, Castalia, 1993.

- (1982): Alcancía. Vol. I. Ida. Vol. II. Vuelta, Barcelona, Seix Barral.

Conget, José María (2002): Viento de cine. El cine en la poesía española de expresión castellana (1900-1999), Madrid, Hiperión.

Costa Staksrud, Liliana (2001): "Rosa Chacel: el artificio de la memoria", en Cristina Segura Graiño (coord.), Feminismo y misoginia en la literatura española, Madrid, Narcea Ediciones, pp. 187-202.

De la Fuente, Inmaculada (2002): Mujeres de la posguerra. De Carmen Laforet a Rosa Chacel: historia de una generación, Barcelona, Planeta.
Donapetry, María (2006): Imagi/nación: Ia feminización de la nación en el cine español y latinoamericano, Barcelona, Fundamentos (69-79).

Escabias Lloret, Pilar (2001): "Mujer y educación", en Silvia Capporale Bizzini/ Nieves Montesinos Sánchez (eds.), Reflexiones en torno al género. La mujer como sujeto de discurso, Alicante, Publicaciones de la Universidad de Alicante.

Fernández, Luis Miguel (1992): El neorrealismo en la narración española de los años cincuenta, Santiago de Compostela, Universidad de Santiago de Compostela.

- (1997): "Pardo Bazán y el cinematógrafo de los primeros tiempos", en José Manuel González Herran (ed.), Estudios sobre Emilia Pardo Bazán: In Memoriam Maurice Hemingway, Santiago de Compostela, Universidad de Santiago.

Fortes, Susana (2002): Adios, muñeca. Cuaderno de cine, Madrid, Espasa Calpe.

Freixas, Laura (2007): Adolescencia en Barcelona hacia 1970, Barcelona, Destino.

Garcia-Abad García, M. Teresa (2006): "Lirismo, narración y memoria en Almudena Grandes y Juan Vicente Córdoba: Buscando una película, Aunque tú no lo sepas, en "El vocabulario de los balcones", en Julie Amiot y Jean-Claude Seguin (eds.), Image et pouvoir, Lyon, Université Lumière, pp. 447-457.

- (2007): "Mnemosyne o el imperio de los sentidos. Literatura e imagen en Almudena Grandes: Malena es un nombre de tango", Iberoamericana, n. ${ }^{\circ} 27$, pp. 25-38.

Gonzalvo Vallespi, Ángel (1996): La memoria cinematográfica del espectador. Panorámica sobre los cines en Teruel, Teruel, Seminario de Arqueología y Etnología Turolense.

Gubern, Román (1994): Benito Perojo. Pionerismo y supervivencia, Madrid, 
Ministerio de Cultura/Filmoteca Española.

Gunning, Tom (1994): "La estrella y el telescopio. Mr. Griffith, Florence Lawrence, Mary Pickford y la aparición de la estrella, 1908-1912", Archivos de la Filmoteca (n. ${ }^{\circ} 18$, octubre), pp. 43-65.

Hansen, Mirian (1991): Babel and Babylon: Spectatorship in American Silent Film Cambridge, Harvard University Press.

Jurado Arroyo, Rafael (1997): Los inicios del cinematógrafo en Córdoba, Córdoba, Filmoteca de Andalucía.

Kirkpatrick, Susan (2003): Mujer, modernismo y vanguardia en España (18981931), Madrid, Cátedra.

Kuhn, Annette (1984): "Géneros de mujeres. Teoría sobre el melodrama y el culebrón", Secuencias (2002), n. ${ }^{\circ} 15$, pp. 7-17.

Labanyi, Jo (2002): "Historia y mujer en el cine del primer franquismo", Secuencias, 15, pp. 42-59.

León, María Teresa (2003): Fábulas del tiempo amargo y otros relatos. Edición de Gregorio Torres Negrera, Madrid, Cátedra.

López Alonso, Covadonga (1993): Edición, introducción y notas a Dolores Medio, Diario de una maestra, Madrid, Castalia.

López Serrano, Fernando (1999): Madrid, figuras y sombras. De los teatros de titeres a los salones de cine, Madrid, Editorial Complutense.

Loyo, Hilaria (2002): "Las estrellas y los deseos femeninos bajo la mirada de la historia: el caso de Marlene Dietrich", Secuencias, n. ${ }^{\circ}$ 15, pp. 18-31.

- $\quad$ (2005): "En la estela de Carmen: Marlene Dietrich en The Devil is a Woman", Archivos, 51, pp. 49-65.

Mari, Jorge (2003): Lecturas espectaculares. El cine en la novela española desde 1970, Madrid, Ediciones Libertarias.
Martín Gaite, Carmen (1953): Un día de libertad, El balneario, Barcelona, Bruguera, 1983.

- (1958): Entre visillos, Barcelona, Destino, 1984.

- (1978): El cuarto de atrás, Barcelona, Destino.

- (1992): Nubosidad variable, Barcelona, Anagrama.

- (1995): "Reflexiones en blanco y negro", Academia. Revista del Cine español. Los dos espejos (12, octubre), pp. 54-57.

- (1996): Lo raro es vivir, Barcelona, Anagrama.

- (2006): Esperando el porvenir. Homenaje a Ignacio Aldecoa, Madrid, Siruela.

Mateos Miera, Eladio (2003): "María Teresa León y el cine", en Gonzalo Santonja (coord.), Homenaje a María Teresa León en su centenario, pp. 297-309.

Matute, Ana María (1957): "Los niños buenos", Algunos muchachos y otros cuentos, Barcelona, Salvat, 1970.

McCabe, Janet (2004): Feminist Film Studies. Writing the Woman into Cinema, London and New York, Wallflower Press.

Medio, Dolores (1953): Nosotros, los Rivero, Barcelona, Destino, 1970.

Merino, José Maria (1982): Cuentos del reino secreto, Madrid, Alfaguara.

Morris, C.B. (1980): This Loving Darkness. The Cinema and Spanish Writers 1920-1936, New York, Oxford University Press.

Mulvey, Laura (1981): "Placer visual y cine narrativo", Eutopías, Vol. 1, 1988.

Nieva de la Paz, Pilar (1993): Autoras dramáticas españolas entre 1918 y 1936, Madrid, Consejo Superior de Investigaciones Científicas.

Paech, Anne / Paech, Joachim (2000): Gente en el cine, Madrid, Cátedra, 2002.

Pardo Bazán, Emilia (1908), "El cinematógrafo" (La ilustración artística, 1406),
Archivos de la Filmoteca, 51 (octubre, 2005), pp. 153-155.

- (1920), "El cinematógrafo" (La Esfera Cinematográfica), Archivos de la Filmoteca, 51 (octubre, 2005), pp. 157161.

Pedraza, Pilar (1998): Máquinas de amar. Secretos del cuerpo artificial, Madrid, Valdemar.

Peña Ardid, Carmen (1999): "La imagen y el imaginario fílmico en la novela española contemporánea", en C. Peña Ardid (coord.), Encuentros sobre Literatura y Cine, Instituto de Estudios Turolenses/ Caja Inmaculada, pp. 37-64.

- (2002a): "El derecho a decir 'no'. La tía Tula y la crítica", en Carmen Becerra (ed.), Lecturas: Imágenes, 2, Mujer, adulterio y cine, Pontevedra, Mirabel Editorial, pp. 441-454.

- (2002b): "Intertextualidad e intermedialidad. Pensar el cine desde la novela", en Carlos F. Heredero (coord.), La imprenta dinámica. Literatura española en el cine español, Cuadernos de la Academia (núms. 11/12), academia de las Artes y las Ciencias Cinematográficas de España, pp. 447-470.

Pérez Merinero, Carlos y David (1974): En pos del cinema, Barcelona, Anagrama.

Piera, Julia (2006): Conversaciones con Mary Shelley, Barcelona, Icaria.

Quiroga, Elena (1953): "Trayecto Uno", en Alicia Redondo Goicoechea (ed.), Relatos de novelistas españolas. 19391969, Madrid, Castalia, 1993.

Redondo Goicoechea, Alicia (2003): "Escritoras hispánicas", en Anna Caballé (dir.), La vida escrita por las mujeres. Lo mío es escribir. Siglo XX, Barcelona, Círculo de Lectores, pp. 17-50.

Reyes, Miriam (2001): Espejo negro, BarceIona, DVD Ediciones.

Riambau, Esteve y Torreiro, Casimiro (1998): Guionistas en el cine español. Quimeras, picarescas y pluriempleo, Madrid, Cátedra. 
Rins, Silvia (2001): La emoción sin nombre. Amor y deseo en el cine, Cáceres, Caja Extremadura/Diputación Provincial de Cáceres.

Rodoreda, Mercè (1962): La plaça del diamant/ La plaza del diamante, Barcelona, Edhasa, 1982.

- (2008): Cuentos. Traducción Ana María Moix, José Batlló y Clara Janés, Barcelona, Edhasa.

Rodríguez-Fisher, Ana (1993): edición, introducción y notas a Rosa Chacel, Barrio de Maravillas.

Roig, Montserrat (1977): El temps de les cireres/ Tiempo de cerezas, Barcelona, Argos Vergara, 1980.
Romero, Luis (1952): La noria, Barcelona, Destino.

Ruiz Guerrero, Cristina (1997): Panorama de escritoras españolas, Vol. II, Cádiz, Servicio de Publicaciones de la Universidad de Cádiz.

Sánchez Saornil, Lucia (1996): Poesía, Valencia, Pre-Textos.

Sánchez Vidal, Agustín (1996): El siglo de la luz. Aproximaciones a una cartelera. Vol. I. Del kinetógrafo a Casablanca (1896-1946).- Vol. II. De Gilda a La Red (1947-1996), Zaragoza, Caja de Ahorros de la Inmaculada.

Santos Fontela (1975): "Amor y desamor, sexo, antierotismo y represión en el cine español", en AA.W., 7 trabajos de base sobre el cine español, Valencia, Fernando Torres, pp. 110-138.

Stacey, Jackie (1994): Star Gazing. Hollywood cinema and female spectatorship, London and New York, Routledge.

Tusquets, Esther (1981): Siete miradas en un mismo paisaje, Barcelona, Anagrama, 1998.

- (2008): Habíamos ganado la guerra, Barcelona, Tusquets.

Utrera Macías, Rafael (2000): Film Dalp Nazari. Productoras andaluzas, Consejería de Cultura/Filmoteca de Andalucía. 